\title{
Proměny Pražského Quadriennale
}

\author{
Amálie Bulandrová
}

\begin{abstract}
Abstrakt
Předkládaný text se zaměřuje na posuny v prezentaci scénografie během Pražského Quadriennale scénografie a divadelního prostoru $(P Q)$. Studie vychází z diplomové práce obhájené na Katedře divadelních studií FF MU v roce 2016 a představuje dílčí část tohoto výzkumu; konkrétně fenomén výstavnictví a s ním související médium instalace v kontextu $P Q$. Vycházím přitom z přesvědčení, že v průběhu více než padesáti let své existence muselo $P Q$ projít jistou transformací: ta by se $v$ prrípadě samotného vystavování dala charakterizovat posunem od statických artefaktů k performativnímu ztvárňování expozic. V současné době vznikají různé teatralizované instalace, které návštěvníci nejen tělesně zažívají, ale také společně vytvářejí v konkrétním výstavním prostoru. $V$ druhé části práce je proto nabídnuta analýza vybrané expozice, jejímž účelem je demonstrovat, jak jsou současné výstavní formy konstruovány ve vztahu k návštěvníkům akce.
\end{abstract}

\section{Klíčová slova}

Pražské Quadriennale, PQ 2007, PQ 2011, PQ 2015, PQ 2019, scénografie, performance design, Arnold Aronson, vystavování scénografie, stage design, performance space, instalace

\begin{abstract}
This paper focuses on shifts in presenting scenography within the world's largest exhibition of it - Prague Quadrennial of Performance Design and Space (PQ). It is only logical, that with more than fifty years of its existence, $P Q$ has undergone a fundamental transformation. How can we exhibit scenography, an artistic discipline which is based on a live action? What approaches were employed fifty years ago and what are the current trends? I would argue that exhibiting of scenography moved from stationary objects towards performative or theatrical environments which resulted in establishment of a new-specific artistic discipline. Now the attendees not only experience the exhibits through their bodily actions, but also co-create them in actual physical space. To demonstrate that the notions of body and physical intentionality are essential for this 'new art-form', concepts of the corporeal schema (MerleauPonty) is applied while analysing chosen installations.
\end{abstract}

\section{Key words}

Prague Quadrennial, PQ 2007, PQ 2011, PQ 2015, PQ 2019, scenography, performance design, Arnold Aronson, exhibition of scenography, stage design, performance space, installation 
„[...] Tento výjimečný projekt byl již oceněn za inovativní přístup ke scénografii, a neobyčejný způsob, jakým byl realizován, jej zařadil do nominací v mnoha dalších kategoriích. Prezentace původního projektu v expozici představené na PQ využívá scénografii způsobem, který dále napomáhá rozvíjení postupů, jakými lze sloučit naraci se scénografií. Tento projekt nám umožňuje pochopit, čeho je možné ve scénografii dosáhnout, užijeme-li niterné esence divadla v sociálním a politickém kontextu.“ (Archiv PQ 2015: Estonsko) ${ }^{1}$

Těmito slovy zdůvodnila mezinárodní porota Pražského Quadriennale scénografie a divadelního prostoru 2015 udělení ocenění Zlatá Triga za nejlepší expozici projektu Sjednocené Estonsko, jenž prezentoval fiktivní hnutí založené Divadlem NO99. Jednalo se o expozici, která se odehrávala na několika úrovních: návštěvník se nejprve dostal do výstavního prostoru, tj. jedné z místností Topičova salonu v Praze, který svým uspořádáním připomínal luxusní klubovnu. Kromě kožených křesílek typu Barcelona od Ludwiga Miese van der Rohe, béžového koberce a podobně barevných tapet se zde nacházely velké plakáty s logem a portréty (pravděpodobně členů nějakého sdružení, viz obr. 1, 2). Zároveň se v expozici promítal film mapující vznik a aktivity původně fiktivního politického hnutí estonského divadla NO99, které se „během dvou měsíců stalo relevantní politickou silou, které průzkumy přisuzovaly 25 \% hlasů“ (Archiv PQ 2015: Estonsko). Díky portrétům na plakátech a všudypřítomnému logu si mohl návštěvník po zhlédnutí filmu uvědomit, že prostor, ve kterém se aktuálně nachází, má představovat salonek náležející právě tomuto smyšlenému hnutí. Byl-li pak navíc v expozici přítomen ve dnech 18.-20. června mezi 10:00 až 18:00, zažil i aktivaci prostoru prostřednictvím př́ítomnosti samotných členů Sjednoceného Estonska a jejich performance.

Předkládaná studie se zaměřuje na způsoby prezentace scénografie během největší světové výstavy této umělecké disciplíny - Pražského Quadriennale scénografie a divadelního prostoru (dále $P Q$ ). Vzhledem ke skutečnosti, že tato výstava byla založena v roce 1967 a probíhá každé čtyři roky dodnes, je jistě nasnadě, že dochází k její průběžné transformaci. Jakým zpo̊sobem můžeme vystavit scénografii - uměleckou disciplínu založenou na živé akci? Jaké přrístupy byly využívány před padesáti lety a jaké jsou současné trendy? Jaký typ scénografie (oceňované) expozice zhmotňují?

$\mathrm{Z}$ výše uvedeného př́kladu je patrné, že scénografie je dnes na $P Q$ prezentována také jako svébytná transdisciplinární praxe výtvarného ztvárňování performativních prostředí, potažmo jako každodenní realita, ve které je působení každého z nás performativním aktem. Tento způsob chápání, a tedy vystavování scénografie je ovšem v kontextu $P Q$ většinově platný teprve v rámci posledních zhruba 20 let: dříve se zde totiž vystavovaly především hmotné artefakty související s procesem vzniku scény a dokumentací (scénáře, návrhy, modely, kostýmy, rekvizity atd.) (ARONSON 2008: 11). Současné ročníky přehlídky naopak připomínají spíše performativní festival a nejedná se přitom pouze o četné doprovodné akce, workshopy, performance apod., na kterých by se dalo uvedené směřování demonstrovat. Naopak se i v rámci výstavních instalací

Více na http://2015.pq.cz.s3.amazonaws.com/www/program/mezinarodni-vystava-zemi/ceny-pq.html. 


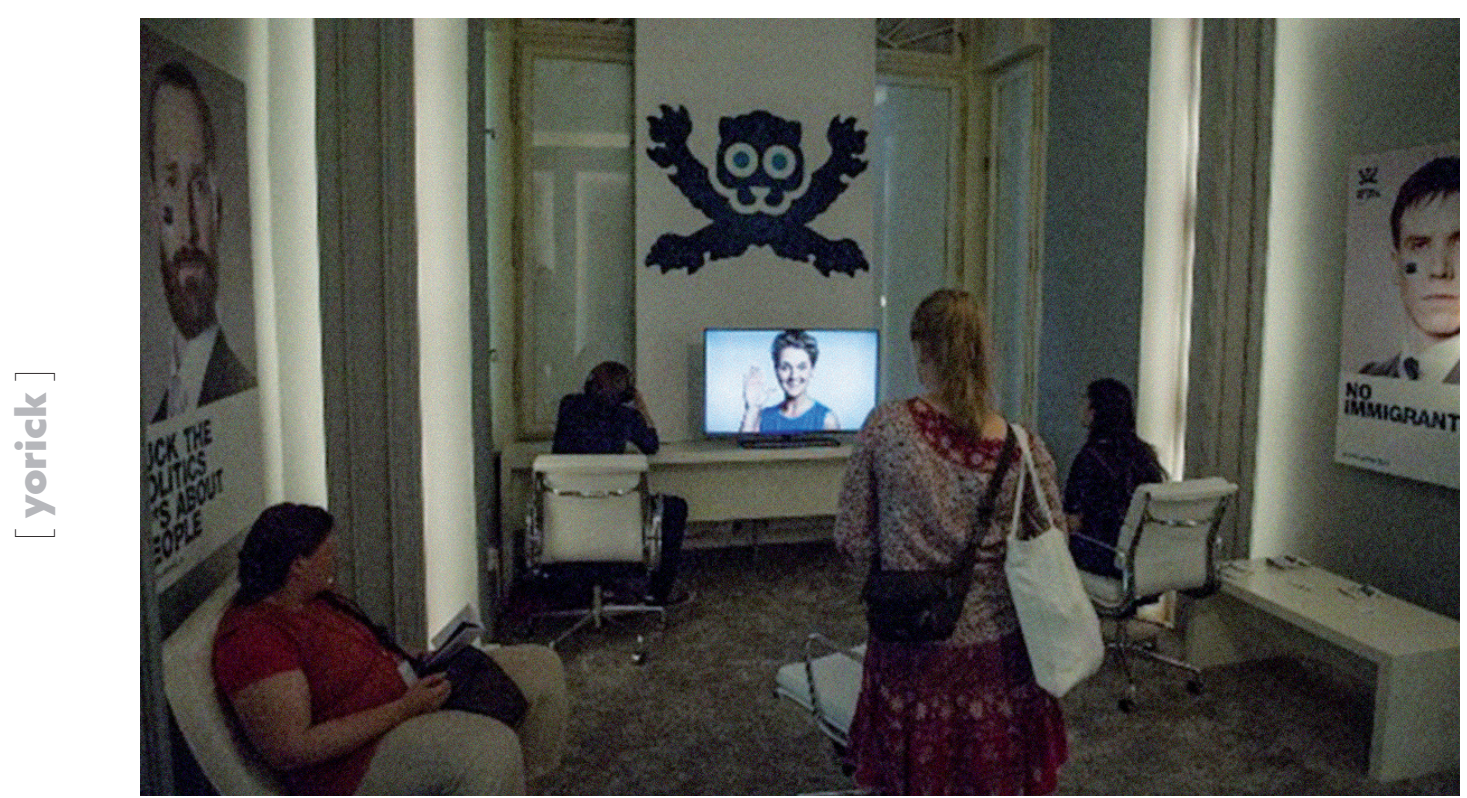

Obr. 1: Expozice Sjednocené Estonsko. Divadlo NO99. Archiv PQ 2015: Estonsko.

Foto Martina Novozámská. Dostupné online na http://2015.pq.cz.s3.amazonaws.com/ www/program/estonsko.html\#\&gid=undefined\&pid=11.

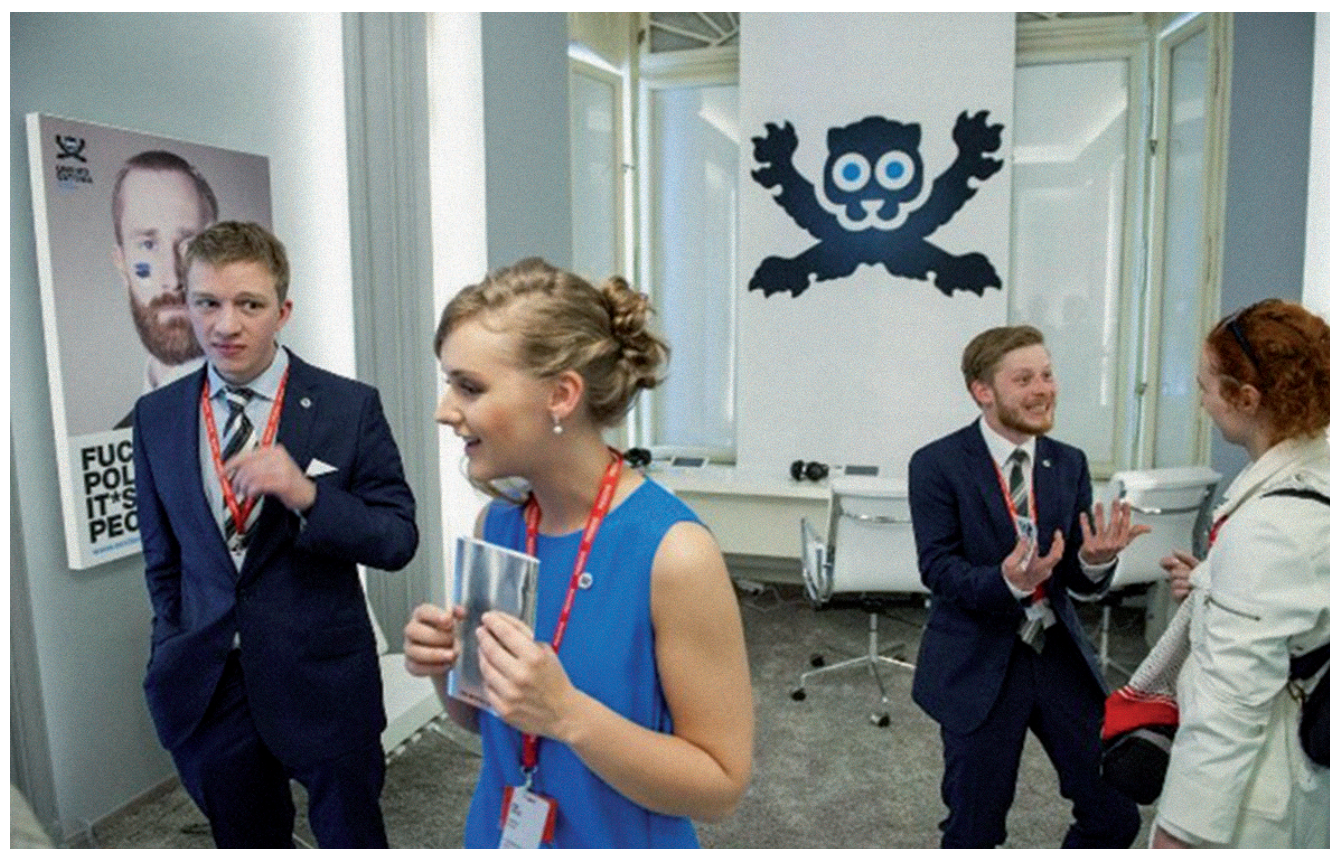

Obr. 2: Expozice Sjednocené Estonsko. Divadlo NO99. Archiv PQ 2015: Estonsko. Foto Martina Novozámská. Dostupné online na http://2015.pq.cz.s3.amazonaws.com/ www/program/estonsko.html\#\&gid=undefined\&pid=14. 
dnes nezřídka setkáváme se svébytnými scénografickými strukturami, které existují jak v rámci expozičního prostoru, tak v prostředí okolní krajiny či politicko-společenské situace a zakládají se na performativním jednání svých aktérů i návštěvníku-spoluaktérů. Níže v textu proto přibližuji tyto „teatralizované environmenty“ (ARONSON 2008: 11) a zamýšlím se nad tím, jaký typ zážitku návštěvníkům nabízejí.

Předkládaný text se tedy nesnaží rozebírat, co vše - potažmo v jakém smyslu - je dnes možné považovat za scénografii, případně navrhnout novou definici této disciplíny. Cílem není ani zmapovat dopodrobna všechny výstavní strategie, se kterými se na $P Q$ můžeme setkat; vědomě zde problematiku zobecňuji, když odhlížím například od té skutečnosti, že se na každém ročníku prezentuje více než 70 účastnících se zemí s rozlišným finančním rozpočtem a kulturním zázemím.

Předkládaná práce si naopak klade za cíl zamyslet se nad tím, jak se výše uvedená definice scénografie odráží v současné koncepci $P Q$; přiblížit některé způsoby vystavování scénografie a ukázat, jak se dnešní pojetí této disciplíny liší oproti její prezentaci v době vzniku přehlídky. Analýzou vybraných expozic chci dále demonstrovat, jak jsou současné scénografické výstavní formy konstruovány ve vztahu k divákovi. Na základě charakterizování specifické proměnlivosti scénografických expozic v rámci času, prostoru a interakce s přítomnými návštěvníky v závěru navrhuji, že představují specifickou uměleckou formu podobnou umění instalace (Installation Art). Pro ověření hypotézy, že je tato umělecká forma založena na tělesné zkušenosti (tj. fyzickém prožitku), kdy návštěvníci $P Q$ expozice nejen prožívají prostřednictvím svých „aktivovaných těl“, ale také je spoluvytvářejí ve skutečném fyzickém prostoru, aplikuji na vybrané instalace koncept tělesného schématu Maurice Merleau-Pontyho.

Pro zodpovězení uvedených výzkumných otázek je také podstatné zamyslet se nad tím, jaký typ akce $P Q$ představovalo v době vzniku a jaké jsou naopak jeho současné strategie. V předkládané studii proto nejprve nabízím a) rozbor dobových textů, vážících se ke scénografické tvorbě a k založení její samostatné výstavy v bývalém ČSSR (1967), b) komparaci s víceméně současnými způsoby nazírání na fenomén scénografie v rámci $P Q$ a c) analýzu vybraných současných expozic, pro které je zásadní tělesný prožitek. V závěru docházím ke konstatování, že současný multidisciplinární koncept scénografie je zásadní pro pochopení vizuální inscenace „každodenního života“ a její manipulace prostřednictvím obrazů.

\section{Kontext výzkumu}

Předkládaný text vychází z diplomové práce obhájené na Katedře divadelních studií Filozofické fakulty Masarykovy univerzity v roce 2016, která se zabývala způsoby vystavování scénografie během tří vybraných ročníků Pražského Quadriennale. Konkrétně se jednalo o rozbor vybraných expozic $P Q$ 2007, 2011 a 2015 a o zmapování změn v pojímání a vystavování scénografie od založení akce dodnes. Každý z analyzovaných ročníků přitom definovala různá specifika, at již se jednalo o místo konání, téma či odbornou porotu vybírající oceněné expozice. Společný jmenovatel naopak představovala 
jejich umělecká vedoucí Sodja Zupanc Lotker, jež během svého působení ve funkci evidentně vnímala postupné změny směru, kterým se ubíralo a stále ubírá současné divadlo a scénografie, a svými kurátorskými a dramaturgickými zásahy jim v každém ze tř́ zmíněných ročníků umožnila se plně projevit.

Právě poslední ze zmíněných ročníků $(P Q 2015)$ by se dal považovat v kontextu úvah o smyslu akce za přelomový. Po jeho uskuteční totiž vznikla diskuse tázající se, zda se na $P Q$ ještě vůbec setkáváme se scénografií. ${ }^{2}$ I tato skutečnost vedla organizátory $P Q$ k uspořádání mezinárodního symposia Proměny Pražského Quadriennale od roku 1999, jehož svolání odůvodnili těmito slovy: „Scénografie v tom nejširším pojetí totiž přesahuje do několika uměleckých oborů, od vytváření performativního prostředí přes osvětlení, zvuk a návrhy kostýmů až po využití multimédií a site-specific projektů. “3 Hlavním cílem symposia proto bylo zhodnotit nejdůležitějš́ aspekty tohoto vývoje, což v reálu vedlo např́ílad k diskuzi o proměně $P Q$ coby výstavy ve festival nebo o rozšiřování významů pojmu scénografie a roli národních kurátorů.

$\mathrm{V}$ roce 2019 se uskutečnil další, v pořadí již 14 . ročník $P Q$, který netvořil součást mého původního magisterského výzkumu. Uměleckou ředitelkou se stala scénografka Markéta Fantová a jako místo konání posloužily prostory Výstaviště Praha. Zatímco předchozí ročník $P Q$ doplňoval podtitul „HudbaPočasíPolitika“, který vymezoval tř̌i hlavní témata, a tedy obsahové zaměření akce na nehmatatelné, nemateriální, neviditelné části scénografie, které ji (nás) ovlivňují, a na jejich společenskou funkci, nesl poslední ročník podtitul „Imaginace.Transformace.Reflexe“. Namísto otázky, „proč děláme věci tak, jak je děláme?" se tedy obsahové směřování soustředilo na otázku, „komu je naše práce určena?“ (FANTOVÁ a LEE 2019: 9) Nejen prostřednictvím expozic, ale také díky odborným publikacím dovezeným v rámci tohoto ročníku do Prahy, at již do obchodu $P Q$ nebo přihlášených do soutěže o nejlepší publikaci, ${ }^{4}$ mohl návštěvník akce zřetelně zaznamenat posun v úvahách o scénografii. Demonstrovaly jej tituly jako Beyond Scenography (HANN 2018), Scenography Expanded (MCKINNEY a PALMER 2017), The Model as Performance (BREJZEK, WALLEN a DI BENEDETTO 2018) či The Routledge Companion to Scenography (ARONSON 2018) apod., které tematizují scénografii i prostřednictvím úvah založených na reflexi $P Q 2015$. Za společný rys uvedených publikací by se zjednodušeně řečeno dala

2 Nutno však podotknout, že obdobné diskuse doprovází akci takřka od jejího vzniku, jak uvádím níže v textu. Jako př́k lad polemiky po $P Q 2015$ uved'me tu z periodika Divadelni noviny, kterou otevřel Josef Herman následujícím prohlášením: „V každém případě se $P Q$ dostalo do situace, kdy je třeba zvážit jeho další smysl nahrazovat ho performancemi, umělými prostory, hračičkařením podle mého problém neřeší, ale obchází." Herman zde tematizuje právě otázku „vystavitelnosti“ divadelní scénografie. Do diskuze vnáší téma kvality kvantitativně opulentní akce také teoretička scénografie Helena Albertová, jež se pozastavuje především nad absencí scénografie v rámci celé výstavy: „Ale především - bylo tu tak málo scénografie!“ (HERMAN: 2015). Tím dává jasně najevo, že pro ni scénografie představuje něco jiného než např́klad pro uměleckou ředitelku $P Q$ Sodju Lotker, vnímající tento termín ve vztahu ke každému sdílenému - performativnímu prostředí (LOTKER 2015).

3 Celé sympozium bylo pořadateli (Institut umění - Divadelní ústav) nahráváno a následně zveřejněno na YouTube. Dostupné online na https://www.youtube.com/watch?v=uhikN9U0b5U\&t=257s.

4 Výstava děl oceněných Cenou za nejlepší scénografickou publikaci se konala ve Střední hale Průmyslového paláce. 
označit snaha rozšiřovat povědomí o tom, co vše můžeme za scénografii považovat a jak se k ní vztahovat. ${ }^{5}$

\section{Scénografie a PQ 1}

V návaznosti na světové úspěchy československých scénografư během Biennale jevištního výtvarnictví v São Paulo bylo v roce 1967 založeno Pražské Quadriennale jako mezinárodní soutěžní přehlídka jevištního a kostýmního výtvarnictví a divadelní architektury. $\mathrm{V}$ textech ideového autora $P Q$ Vladimíra Jindry se dozvídáme, že hlavním cílem takto koncipované přehlídky bylo „[...] postižení specifičnosti jevištního výtvarnictví, neoddělitelnosti scénografie od režie a všech ostatních složek dramatického díla a o zdůraznění jejich syntetického charakteru“ (JINDRA a PTÁČKOVÁ 1967: 11). Ještě před vznikem této soutěžní mezinárodní přehlídky, tj. v 60. letech 20. století, navíc v Praze existovaly dokonce dva odborné scénografické ústavy (Scénografický odbor Divadelního ústavu a Scénografický ústav), které tento umělecký obor zkoumaly, dokumentovaly a vydávaly i několik odborných scénografických periodik. Uvedené skutečnosti svědčí o výlučném postavení scénografie, která stála v centru tehdejšího kulturního dění. ${ }^{6} \mathrm{Na}$ otázku, jak došlo k tomuto takřka až neuvěřitelně systematickému zájmu právě o scénografii, odpovídá např́íklad teatroložka Helena Albertová: „Bylo to období, kdy Josef Svoboda opustil představu tradiční dekorace a tvrdil, že i když vytvoří ty nejkrásnější obrázky, pořád je to kašírka, a že je tedy nutné přejít k novým médiím. To zaujalo Miroslava Kouřila a vznikla idea, že se musí systematizovat abeceda scénografie, její jazyk [...]“ (ALBERTOVÁ 2009).

Co přesně tehdy odlišovalo scénografii od jevištního výtvarnictví zodpovídá opět teoretik a programový zakladatel $P Q$ Vladimír Jindra. V návaznosti na strukturalistické pojetí divadelní inscenace Otakara Zicha a Jana Mukařovského se ve své stati „Specifičnost scénografie“ z druhé poloviny 60 . let zamýšlí nad rolí výtvarné složky inscenace a nad jejím vztahem k dalším složkám divadelního artefaktu. Jindra zde navrhuje čtyři základní etapy jejîho vývoje: jevištní dekoratérství a výprava, jevištní výtvarnictví, scénické výtvarnictví, scénografie. Jako etapu vývojově nejvyspělejší tedy Jindra chápe právě scénografii, kterou podle něj charakterizuje týmová práce a integrace umění, vědy a technologií, které ji zároveň odlišují od předcházející formy scénického výtvarnictví. ${ }^{7}$

5 Jako př́klad uved'me citaci teoretika scénografie, amerického teatrologa Arnolda Aronsona, který v poslední ze jmenovaných knih definuje scénografii těmito slovy: "This multidisciplinary concept of scenography, together with the emphasis on spatiality and the unity of creation, is crucial to understanding the difference between design and scenography. Scenography, as I have written elsewhere, is the 'all-encompassing visual spatial construct' of the theatrical event and embodies the process of change and transformation that is an inherent part of the physical vocabulary of the stage' (Aronson 2005: 7). As a means of understanding performance, scenography should, in fact, lie at the heart of any analysis of theatrical and performance art" (ARONSON 2018: 8).

6 „[Scénografie byla] respektovaná, vážená. Měla všechny předpoklady dokonce zlidovět [...]. Proto bylo jen logické, že vzniklo v roce 1967 Pră̌ské quadriennale." (PTÁČKOVÁ 2009: 133)

7 Barbora Příhodová ve své disertační práci o scénografické tvorbě Josefa Svobody vysvětluje, že přesný rok vzniku studie není znám: „[...] užité př́ílady a také komplexní koncept scénografie [...] napovídá, že byla 

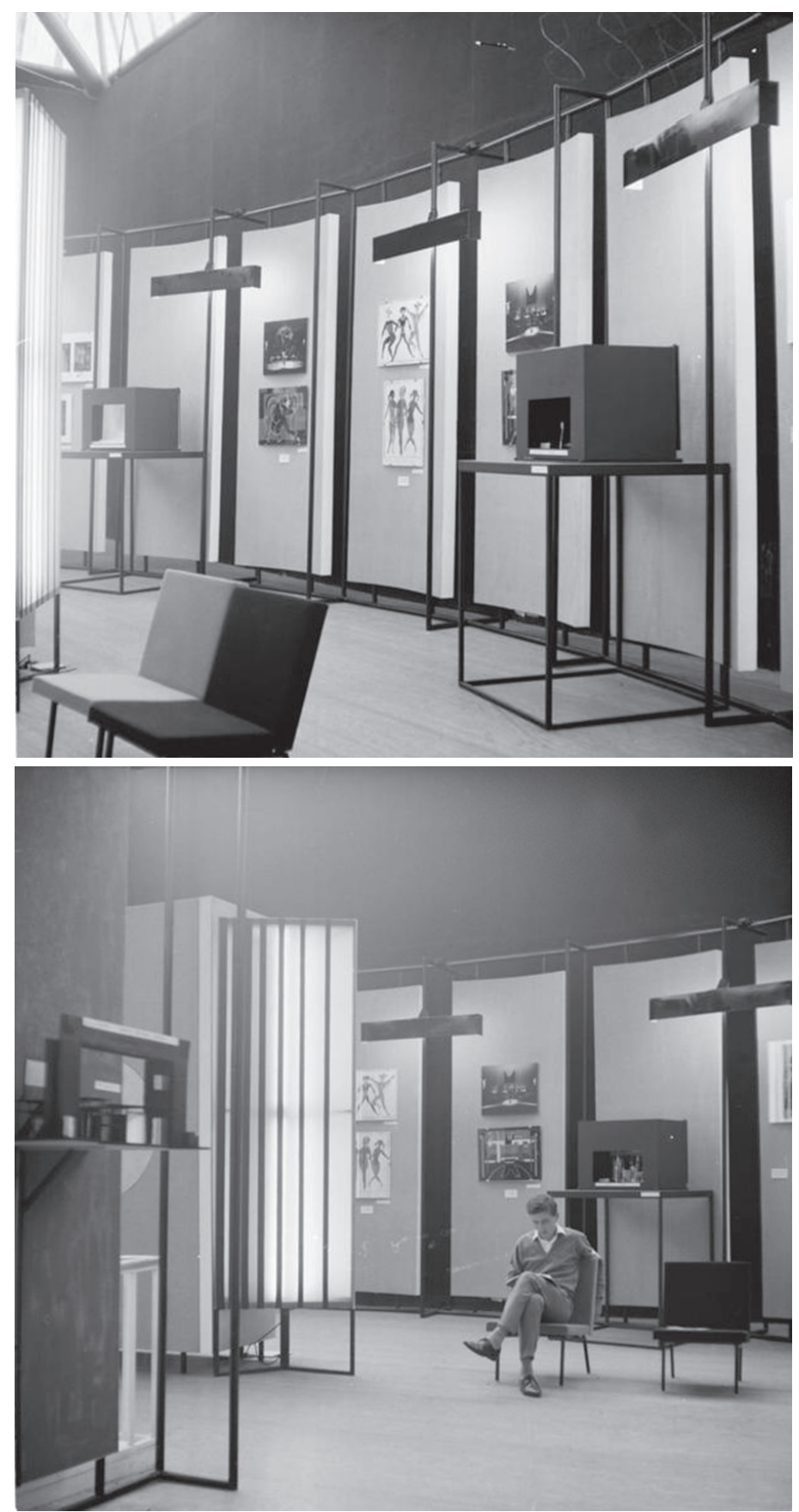

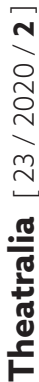

Obr. 3 + 4: Pražské Quadriennale v roce 1967. Francouzská expozice. Archiv PQ. Dostupné online na http://services.pq.cz/en/pq-67.html?itemlD=61\&type =national\#! prettyPhotoAjax[ajax]/3/. 
Z Jindrova textu v katalogu prvního ročníku $P Q 1967$ dále vyplývá, že se založením Pražského Quadriennale dovršila pomyslná cesta etablování scénografie coby svébytného uměleckého žánru, specifického svou neoddělitelností od ostatních složek dramatického umění, tedy svým syntetickým charakterem (JINDRA a PTÁČKOVÁ 1967: 11). Takto chápanou scénografii pravděpodobně nejlépe odrážela historicky první vítězná expozice, která v roce 1967 získala ocenění Zlatá triga v hlavní soutěžní sekci Scénografická a kostýmní tvorba. V této kategorii mohli scenáristé jednotlivých státních expozic sami rozhodnout, zda jejich koncepce bude vedena historicky, teoreticky nebo zda se bude soustředit na problematiku současné tvorby apod. (JINDRA a PTÁČKOVÁ 1967: 11). Mezinárodní porota vybrala jako vítěznou expozici Francie, ${ }^{8}$ jejímž kurátorem byl scénograf a autor baletních libret Yves Bonnat a autory tématu výtvarníci Michel Brunet, Bernard Guillaumot a Claude Verbiése. Bonnat pro expozici vybral díla z prací desítek „výtvarníků (z nichž na dvě stě se věnuje pravidelně scénografii) a architektů (kteří se věnují v mnohem menším počtu výstavbě divadel a kulturních domů) a jsou zjevným znakem skutečnosti, že boj o nový tvar probíhá ve všech divadelních žánrech [...]“ (JINDRA a PTÁČKOVÁ 1967: 85). Z kurátorského textu dále vyplývá, že přestože mezi francouzskými jevištními výtvarníky převládali maliŕi a architekti interiérů, vstupovali v té době do scénografické praxe i architekti a sochaři: „Tento jev vyplývá i ze záměrné jednoduchosti technických postupů, umožněných především využitím světla a nových materiálů, a pak z vlivů, kterými film a televize působí na divadlo“ (JINDRA a PTÁČ́KOVÁ 1967: 85).

První $P Q$ se v roce 1967 konalo v „bruselském pavilonu“, který se do Prahy vrátil z výstavy Expo 58 v Bruselu. Francouzskou expozici zde podle dobových fotografií tvořilo kruhové uspořádání paravánů, tj. zaoblených výstavních stěn, na kterých byly umístěny vybrané skici - různé návrhy scén a kostýmů, stejně jako fotografie z inscenací. Mezi těmito objekty se dále nacházely podstavce pro vystavované makety a modely scén (viz obr. 3 a 4).

\section{Praha není Česko}

Jelikož termín „scénografie“ představuje pojem značně proměnlivého charakteru, jehož význam byl (je) posouván na základě kulturně-historického kontextu, nepřekvapí nás pravděpodobně, že způsob současného prezentování scénografie může být podstatně odlišný než výše uvedené postupy z roku 1967. Jako př́íklad uved’me expozici studentů scénografie na Janáčkově akademii múzických umění v Brně, která během zatím posledního ročníku $P Q 2019$ získala Ocenění za Imaginaci ve Studentské výstavě. ${ }^{9}$ Projekt

\footnotetext{
práce napsána v druhé polovině šedesátých let. Jindra zde př́mo rozvíjí myšlenky Otakara Zicha a svého učitele Jana Mukařovského“" (PŘíHODOVÁ 2012a: 58).

8 Československá expozice v této oblasti nesoutěžila; tuzemští scénografové se prezentovaliv Mimosoutěžní sekci - laureáti Biennale v Sao Paulu, kde byly k vidění vybrané práce Františka Tröstera, Josefa Svobody a Ladislava Vychodila (JINDRA a PTÁČKOVÁ 1967:11-12).

9 Konkrétně jde o skupinu Intelektrurálně, kterou tvoří Anna Chrtková, Andrea Dudková a Jan Matýsek a která se svým návrhem uspěla v otevřené výzvě vypsané Institutem umění - Divadelním ústavem na ztvárnění české expozice ve studentské sekci $P Q 2019$.
} 
s názvem Praha neni Česko tvořila svébytná scénografická struktura, existující jak v rámci výstavního prostoru, tak v prostředí okolní krajiny města Prahy a fungující v několika úrovních: návštěvník se mohl nejprve v pravém křídle Průmyslového paláce setkat se stánkem imaginární cestovní kanceláře Praha není Česko, jehož „pracovníci“ zde nabízeli několik výletů. Pokud návštěvník nabídku přijal a výletu se zúčastnil, stal se z něj spolu-aktér v další expozici - „kurátorované realitě“ vybrané lokality - organizované různými uměleckými týmy. Prostř̌ednictvím těchto výletů bylo možné navštívit např́íklad periferii města Ústí nad Labem (skupina Czechia) nebo strávit den v brdských lesích sbíráním hub (DAMU) či odjet do východních Čech a zúčastnit se sběru jahod a následného „workshopu“ tvorby jahodových knedlíků (JAMU) atd..$^{10}$ Jak vysvětlují autoři projektu, ,[...] vyvedením návštěvníků $\mathrm{PQ}$ mimo Prahu se chceme pokusit o dialog s reálným prostředím, skutečnými lidmi. Základní myšlenkou bylo dostat umění (často širokou veřejností vnímané jako „elitářské“) ven z velkoměstských galerií a divadel a napojit ho na lokální úroveň. “11

Další úroveň expozice tvořil virtuální obraz právě probíhající akce: každý výlet byl totiž delegátkami natáčen, přičemž se záznam přenášel do stánku cestovní kanceláře na Výstavišti a na velkých obrazovkách zde byl promítán. Náhodní kolemjdoucí, i za tímto účelem přicházející návštěvníci, se tak mohli posadit na připravené stoličky před stánkem a sledovat průběh výletu (obr. 5 a 6). Expozice se tedy skládala z několika vzájemně se prolínajících akcí, přičemž fungovala především jako smyslový i fyzický zážitek. Pivo, les, jahody, továrna, místní obchod atd. - vše, co bylo zažíváno během výletů, se stávalo scénografií. Stánek na výstavišti vytvářel kontext výletů po Čechách, díky kterému mohli účastníci vnímat reálnou krajinu právě jako scénografii - k tomu jim dopomáhali průvodci a další aktéři, kteří danému prostředí dávali svým jednáním určitý význam, na jehož utváření se ale aktivně podíleli i samotní účastníci. Scénografie zde představovala prostředek k vytvoření kontextu, bez něhož by zvolené prostředí nedisponovalo kýženými významy, i samotné akce.

Pro projekt Praha neni Česko byl také zásadní fenomén „spolupráce/participace“, kterému se na poli výtvarného umění dostává v posledních zhruba dvaceti letech stále větší pozornosti (ZÁLEŠÁK 2011). Projekty a instalace založené na umělecké spolupráci a participativním umění ( $\mathrm{tj}$. na tvořivé spoluúčasti) představují takový typ umělecké praxe, kde se coby výchozí bod rozumí právě zesílená pozice diváka a kde jsou jednotlivé projekty postaveny zejména na aktivizaci skupin či jednotlivců, kteří se v průběhu akce stávají jejími spolutvůrci (srov. BISHOP 2007: 9-10, 16-18). Jak vysvětluje kurátor a teoretik umění Jan Zálešák, můžeme v rámci tzv. „obratu ke spolupráci“ sledovat (souběžně) dvojí tendenci: „,...] jednak je to zesílený zájem o ,horizontální spolupráci mezi lidmi, kteří mají v uměleckém poli obdobný status - tedy o spolupráci na úrovni umělců, př́ípadně kurátorů. A potom je to spolupráce ,vertikálního charakteru', tj. taková, v níž se do realizace projektu zapojují lidé s nestejným

10 Více například na http://www.prahanenicesko.cz/.

11 Anotace projektu Praha neni Česko. Autoři: Anna Chrtková, Andrea Dudková, Jan Matýsek (FANTOVÁ a LEE 2019: 70). 


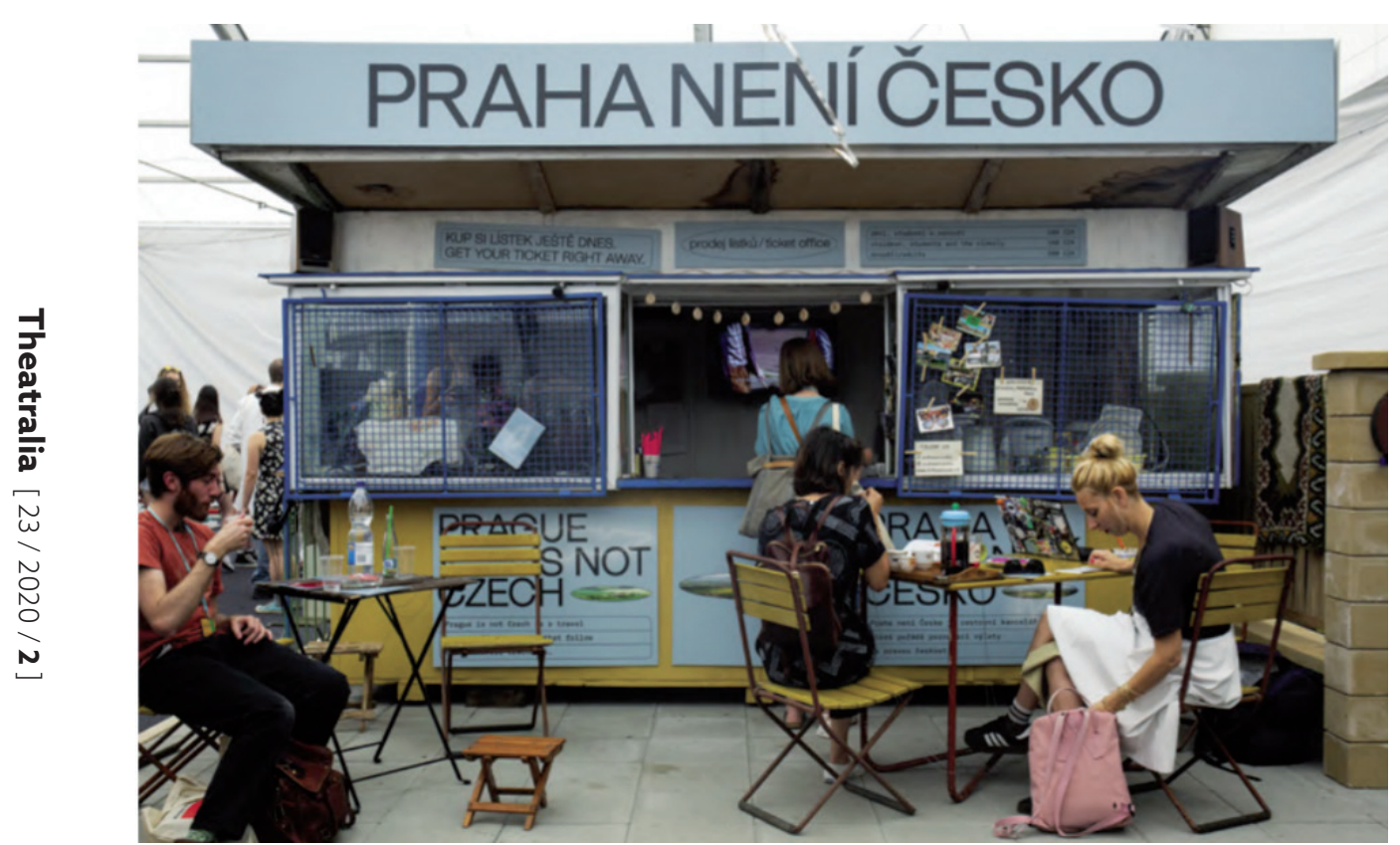

Obr. 5: Expozice Praha není Česko. Skupina Intelektrurálně. PQ 2019.

Foto Adéla Vosičková. Katalog PQ 2020, s. 71. Dostupné online na file:///C:/Users/bulan/ OneDrive/Plocha/studie\%20Theatralia/PQ19-catalogue-web.pdf.

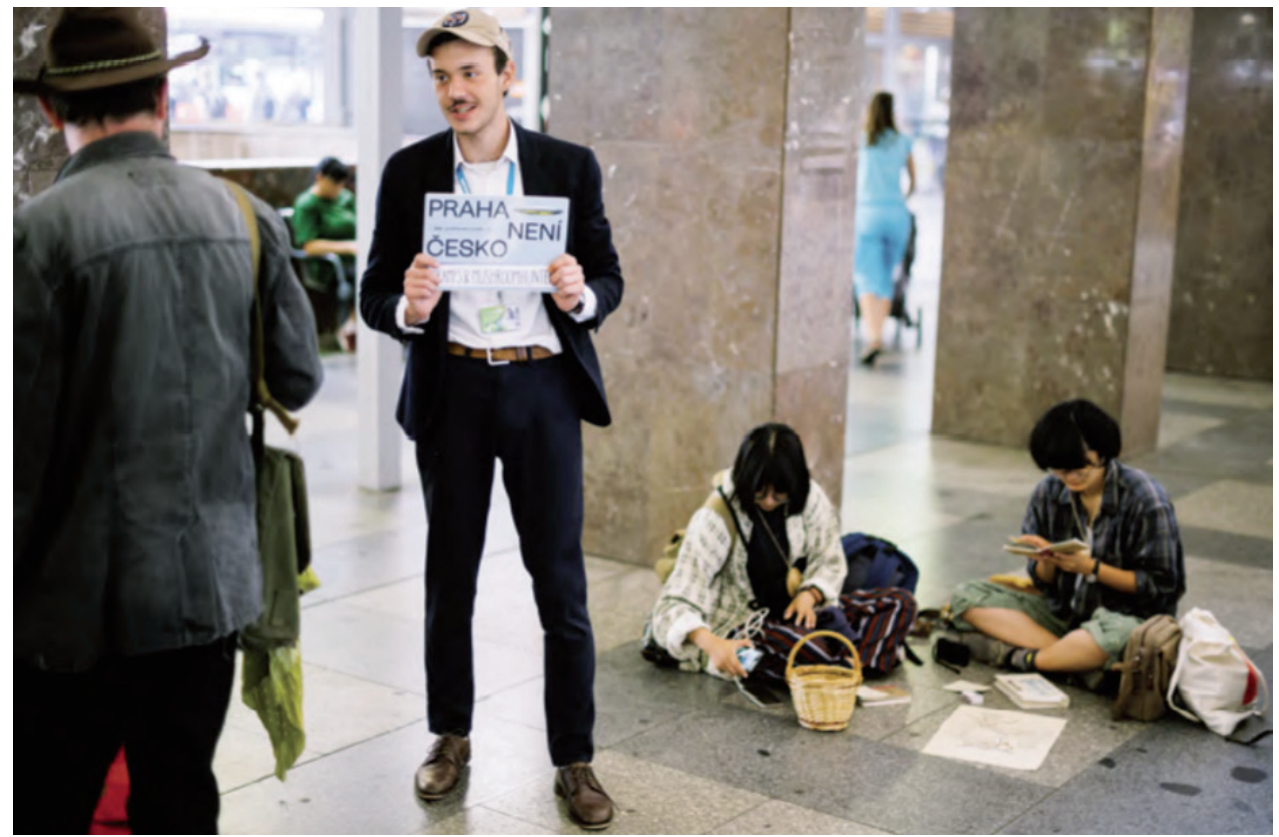

Obr. 6: Expozice Praha není Česko. Skupina Intelektrurálně. PQ 2019.

Foto Adéla Vosičková. Katalog PQ 2020, s. 71. Dostupné online na file:///C:/Users/bulan/ OneDrive/Plocha/studie\%20Theatralia/PQ19-catalogue-web.pdf. 
statusem - na jedné straně umělci (kurátoři) a na druhé straně lidé mimo profesní oblast výtvarného umění. Tedy druh umělecké praxe, označované dnes běžně jako participativní umění“ (ZÁLEŠŚK 2011:10).

První z uvedených tendencí odráží celkovou koncepci projektu Praha neni Česko - autorské trio se totiž rozhodlo přizvat k organizaci dílčích výletů nemalé množství uměleckých subjektů, které dále (plně autonomně) realizovaly své představy o „kurátorované realitě/situaci“12 v jimi vybrané lokalitě. Kromě výše zmíněných autorů tak můžeme za spolu-tvůrce projektu na tzv. „horizontální úrovni“ vnímat i studenty Katedry alternativního divadla DAMU, Katedry činoherního divadla JAMU, Ateliéru Intermedií FAVU či umělecko-antropologickou skupinu Czechia a další. V kontextu spolupráce „vertikálního charakteru“ se pak jedná o samotnou ideu dílčích výletů, jichž se měli účastnit náhodní návštěvníci $P Q$ a to za účelem navázání kontaktu s obyvateli vybrané lokality prostřednictvím nějaké činnosti. ${ }^{13}$

\section{Scénografie a PQ 2}

Z uvedeného prríkladu vyplývá, že současné expozice $P Q$ fungují nezřídka i nezávisle na divadelním představení, tj. že jeden z rozdílů mezi tím, jak byla scénografie definována a pro $P Q$ původně koncipována Vladimírem Jindrou, a tím, co termín scénografie znamená dnes, spočívá v její autonomní pozici vůči celistvému divadelnímu dílu. Vzhledem k této skutečnosti se proto také autoři současných výstavních expozic stále častěji odklání od prezentování existujících scénografických realizací, a naopak je vymýšlí a vytváří př́ímo pro $P Q$ - at již pro jeho „domácí“ prostředí, přidělený výstavní prostor či mimo ně v návaznosti na současnou společensko-politickou situaci.

Na uvedeném posunu se shoduje mnoho teoretiků i praktiků: např́klad americký teatrolog Arnold Aronson v návaznosti na $P Q 2007$ vyjmenovává tři výrazné trendy ovlivňující jak sféru tehdejší scénografické tvorby, tak způsoby jejího vystavování: využívání nedivadelních prostor, architektonických prvků divadelních budov jakožto součásti scénografických návrhů a rozvoj nových technologií, používaných během divadelních produkcí. V kontextu těchto trendů autor promýšlí očividnou změnu ve směřování $P Q$, která podle něj spočívá v přeorientování pozornosti z konkrétních umělců a žánrů - tj. ze zaměření na proměny výtvarného projevu divadelních inscenací - na prezentování scénografie prostřednictvím svébytných scénografických struktur, vytvářených přímo

12 Jedná se zejména o manifestační text Guy Deborda, který vnáší do diskursu o spolupráci v umění pojem „konstruované situace“ (MAGID 2008).

13 Jak vysvětluje Jan Zálešák, souvisí s kolektivní i participativní uměleckou praxí většinou i nějaká forma angažovanosti, kdy se setkáváme „[...] s tendencí k potlačování umělecké autonomie ve prospěch úsilí o dosažení změn v oblasti každodennosti (ve veřejném prostoru, ,ve skutečném světě) a s kritickým vztahem k fungování uměleckého provozu, v němž nadále zůstává klíčovým orientačním bodem individuální autorský génius“ (ZÁLEŠÁK 2011: 10). Uvedenou citaci opět ilustruje ideová koncepce projektu Praha neni Česko, tj. snaha jeho tvůrců a spolutvưrců o upozornění na odtrženost menších (lokálních) center od hlavního města a na společensko-politické důsledky této propasti. Nejedná se přitom o utopičnost - snahu o změnu společenského systému jako celku, ale o malé (dočasné, provizorní) zásahy koncipované v lokálním měřítku. 
pro $P Q$ jakožto performativní prostředí, které označuje termínem „teatralizované environmenty" (theatralized environments; ARONSON 2008: 11).

Jiným příkladem reflexe změny směřování $P Q$ je komentář teatroložky Barbory Př́íhodové, která tento posun charakterizuje coby přehodnocení perspektivy vnímající scénografii jako exkluzivní typ divadelní praxe zaměřující se na způsoby formování jevištního prostoru. Autorka poukazuje na skutečnost, že vše, co se dřive celoplošně označovalo jako scénografie, se z dnešního pohledu jeví jen jako jeden specifický výsek umělecké tvorby, exkluzivní i díky dostupným finančním prostředkům a stabilnímu (společenskopolitickému) zázemí (MCKINNEY, LOTHER a PŘíHODOVÁ 2016: 6). Obdobně vnímá situaci i britská teatroložka Joslin McKinney, jež uvádí, že vystavování scénografie pomocí statických artefaktů je dnes již takřka nahrazeno živou performancí (MCKINNEY, LOTKER a PŘíHODOVÁ 2016: 8). A podobně můžeme vnímat i komentář předního českého scénografa Jaroslava Maliny, který posun charakterizoval těmito slovy: „[po] celou dobu existence PQ zaznívá otázka, jak vystavovat scénografii. Původní forma klasické galerijní přehlídky toho nejlepšího ze světa divadla a jeho scénických podob časem zkameněla“ (HERMAN 2015: nestr.).

Přestože se jedná o fragmentární př́íklady, můžeme zobecnit a shrnout, že nejpozději začátkem 21. století se chápání termínu scénografie začalo postupně zbavovat závislosti na konkrétní divadelní inscenaci či jevištním prostoru a nově se vztahuje k formování jakéhokoliv performativního prostředí, což dále vede k akcentaci jejího procesuálního charakteru namísto výsledného tvaru. Za tímto posunem jistě stojí mnoho činitelů vyvstávajících z kulturně-společenského dění posledních padesáti let. Mezi ty nejvýraznější patří nástup nových médií a jejich využívání v př̌edstavení, tendence opouštět primárně divadelní prostory či odklon od textem fixované formy divadla. Připomenout můžeme i pojem „performativní obrat“ německé teatroložky Eriky Fischer-Lichte, jímž označila tendence v kulturologii vztahující se na materiální ztělesňování významů (FISCHER-LICHTE 2014). V této souvislosti je pak patrné, že ani scénografické realizace (potažmo formy jejich vystavení) nejsou od jisté doby koncipovány pouze za účelem vytvoření „fiktivních světü“ textem fixovaných předloh, ale také jako svébytná prostředí pro interakci mezi aktéry a spoluaktéry.

Pravděpodobně i z důvodu potřeby nového promýšlení, označování a kategorizování takových expozičních forem, které se svou formou vymykají tradičnímu pojetí scénografie, dospělo $P Q$ v roce 2011 ke změně svého názvu. Organizátoři jej po více než čtyřiceti letech fungování přejmenovali z Pražské Quadriennale jevištniho výtvarnictvi a divadelni architektury na Pražské Quadriennale scénografie a divadelního prostoru. Jelikož bylo slovo „jevištní výtvarnictví" nahrazeno pojmem „scénografie“, můžeme hovořit o tendenci rozšiřovat sémantické pole tohoto termínu (ve smyslu „co všechno dnes scénografie znamená??“). V anglické verzi nového názvu byl naopak termín „scenography“ nahrazen a z původního Prague Quadrennial International Exhibition for Scenography and Theatre Architecture se stalo Prague Quadrennial of Performance Design and Space. V anglické verzi tak došlo k proměně opačné: pojem „scénografie/scenography“ byl nahrazen novým termínem. Sodja Zupanc Lotker, jedna z iniciátorek přejmenování přehlídky, charakterizuje pojem „performance design“ v kontextu $P Q$ víceméně jako synonymum pojmu 
„scénografie“: „[s]cenography is considered and used in the Prague Quadrennial terminology as an almost exact synonym of 'performance design'. 'Performance design' is used here instead of 'set design' (that rings too close to setting and decoration), instead of 'stage design' (that limits scenography to the space of stage) and instead of 'theatre design' (that excludes a variety of performative genres)“"14 (WALLING 2015: 37).

V obou př́padech dali organizátoři $P Q$ přejmenováním najevo, že akci otevírají transdisciplinárnímu pojímání scénografie coby performativního prostoru, a to jak uvnitř̆, tak vně „černého boxu“ (divadla) či „bílé krychle“ (galerie). ${ }^{15}$

\section{Výstavní potenciál scénografie}

Stejně jako se v expozicích $P Q$ zrcadlí charakteristické prvky scénografie jakožto disciplíny, je jejich forma definována také požadavky disciplíny odlišné, tedy výstavnictvím v nejširším smyslu slova. Odhlédneme-li od institucionalizované muzejní expozice k výstavním formám typu Prǎ̌ského Quadriennale, dostaneme se k mezinárodním soutěžním přehlídkám a tematickým výstavám, jejichž rozmach spadá opět do šedesátých let minulého století. Tedy do období postupného uvolňování politické situace v tehdejším Československu, kdy se do popředí dostaly „,[...] aktivity směřující k prezentaci československého divadla v zahraničí, k činnosti informační a výstavni“ (PATOČKOVÁ 2009: 28). Myšlena je tím celá řada mezinárodních výstav pořádaných $\mathrm{v}$ tuzemsku i v zahraničí, odehrávajících se i díky samostatnému scénografickému oddělení Divadelního ústavu v Praze. Byli to totiž právě jeho pracovníci, kdo se pod vedením již citovaného Vladimíra Jindry na těchto výstavách podíleli.

Jak v monografii o pavilonu ČSSR na Expo 67 vysvětluje Terezie Nekvindová, využívalo Československo světové výstavy především k navázání ekonomických styků, přičemž si jistě uvědomovalo i potenciál výstav coby prostředku masové komunikace: „V Československu se výstavní tvorba po druhé světové válce etablovala jako samostatná disciplína, v 60. letech, kdy vrcholila obliba výstav a veletrhů, sehrávalo výstavnictví roli masového umění, které podobně jako další hromadné akce pomáhalo utvrzovat občany v přesvědčení o správnosti socialistického zřizení“ (NEKVINDOVÁ et al. 2017: 20). Jak historička umění dodává, dostalo se v tuto dobu také slovo „výstavnictví“ do naučného slovníku, kde bylo definováno jako speciální obor architektury a užitého umění. Kromě umělců se na něm podle definice podíleli nově také scénáristé, přičemž byl kladen důraz na odlišnost aktuálního přístupu od předchozího „aranžerského pojetí“ oboru (NEKVINDOVÁ et al. 2017: 42).

14 Carl H. Walling uvádí tuto citaci ve své disertační práci, autorkami jsou Sodja Lotker a Martina Černá (Intersection: Intimacy and Spectacle) (WALLING 2016: 37).

15 Arnold Aronson ke změně názvu PQ uvádí: „As artistic director Sodja Zupanc Lotker explained, the change in nomenclature was a response to radical shifts in theatre itself. 'In recent decades with found theatre, site-specific theatre, devised theatre, applied theatre, media theatre, interventions, installations and so on, the term "stage design" became too limiting' (Lotker 2015: 8)" (ARONSON 2018: 12). 
Nekvindová dále vysvětluje, že při tematizaci podstaty výstavních expozic se „zdůrazňovalo především ,emocionální ovládnutí diváka v daném prostoru všemi prostředky‘; autoři hovořili přímo o inscenaci výstavy "“16 (NEKVINDOVÁ et al. 2017: 43). O uvedeném svědčí i dobové články v odborném periodiku Acta Scaenographica; v rámci analýzy „výstavní scénografie“ se zde setkáváme s charakteristikami, kterými bývá popisována i divadelní scénografie. Jako prŕíklad uved’me nutnost prrítomnosti publika: „,...] výstava totiž před obecenstvem, nebo vlastně díky obecenstvu teprve ožívá. Výstava bez diváků, stejně jako divadelní představení, je mrtvá, vlastně není“ (SANTAR 1966: 2). Podobně tomu je i s požadavkem na syntetický tvar akce: „Kvalitu celku nelze zvýšit tím, že vyzvedneme význam jedné složky [...]. Rovnoměrný vztah mezi jednotlivými uměleckými složkami je nutný v každém syntetickém umění, at výstavním, divadelním nebo filmovém“ (PROCHÁZKA 1966: 13). Těmito slovy klade Antonín Procházka důraz na ne-zvýhodňování vizuální stránky výstavního díla na úkor jeho ostatních složek, čímž se dostává k rozborům teoretických i praktických pravidel „výstavní scénografie“, jak problematiku nazývá. Zmíněnému pojmu je pak věnována celá řada úvah: o atraktivnosti technických prostředků, o požadavcích na funkčnost výstavní scénografie ve prospěch vyjádření tématu či o jejích výrazových prostředcích (PROCHÁZKA 1966).

Jiný dobový přispěvatel Jindřich Santar ve svém článku dokonce přičítá výstavní tvorbě obdobné schopnosti, jaké autoři publikace The Cambridge Introduction of Scenography z roku 2009 přičítají samotné scénografii, ${ }^{17}$ totiž emocionální a zároveň racionální působení na diváka: „Autor či autoři chtějí přece nejen exponátem, ale i celou skladbou, prostředím výstavy, její atmosférou i režií navodit uměleckou skutečnost tak, aby zasáhla jak racionální, tak emocionální složku divákovy osobnosti“ (SANTAR 1966: 3). V rámci komplexnosti výstavního umění autor dále operuje s pojmy divadelní terminologie, kdy kromě výstavní scénografie rozebírá funkci a nutnost výstavního scénáře, dramaturgie, a zejména pak režie. Tuto skutečnost popisuje i Terezie Nekvindová ve výše zmíněné publikaci Automat na výstavu - podle autorky mělo být právě scénografické pojetí výstavy tím, co zajištovalo vybuzení emocí, tj. mělo jít o „scénickou expozici“ plnou dramatických efektů: „Převzetí řady postupů ze scénografie (včetně audiovizuálních prostředků) a role scénáristy, který měl zajistit, aby se nevystavovaly pouze předměty, ale také myšlenky, jsou jedním z hlavních motorů tehdejšího výstavnictví, někdy označovaného jako ,česká výstavnická škola““ (NEKVINDOVÁ et al. 2017: 43).

Uvedené postřehy svědčí o tendenci chápat výstavní tvorbu podobně jako divadelní inscenaci ve smyslu souhry několika různých složek, které společně konstruují význam, působí na diváka a podléhají určitému organizujícímu principu. Takový příměr najdeme i v kontextu současných úvah o $P Q$, např́íklad opět u Arnolda Aronsona, který po 11. ročníku akce v roce 2007 uvedl: „If the $P Q$ is understood as a performance, then the exhibition hall is its stage, the pavilions and their contents its scenography. What is absent, of course, are the performances to which the exhibits refer, and there is thus a continuous discourse between

16 První vnořený citát (VOTRUBA 1959: 415), druhý (SVOBODA 1975: 23).

17 "Scenography is not simply concerned with creating and presenting images to an audience; it is concerned with audience reception and engagement. It is a sensory as well as intellectual experience; emotional as well as rational." (MCKINNEY a BUTTERWORTH 2009: 4) 
the two"18 (ARONSON 2008: 38). Přirovnáním celého $P Q$ k performanci Aronson mj. upozorňuje na skutečnost, že to, co zde chybělo, byla konkrétní představení, na něž dílčí expozice odkazovaly. Díky této absenci podle Aronsona vzniklo permanentní napětí mezi tím, co je a co není v expozici přítomné, odrážející se ve způsobu vystavení jednotlivých scénografických artefaktů.

Vedle zmíněných artefaktů Aronson jmenuje další tř̌i možnosti vystavení scénografie: 1) statická dokumentace (např. fotografie), 2) kinetická dokumentace (např. video), 3) scénografické artefakty: prezentace artefaktů souvisejících s procesem tvorby (např. návrhy a modely scénografických řešení) či s konkrétní inscenací (kostýmy, rekvizity apod.), 4) alternativní formy vystavení, ve kterých se samotná expozice stává jistým druhem scénografie (ARONSON 2008: 28). Zatímco první dvě varianty chápe pouze jako dokumentaci, považuje Aronson třetí ze způsobů za jistý druh pravdivé výpovědi o scénografii: artefakty zachycující proces tvorby (scénické návrhy) totiž představují objekty, které skutečně svědčí o tom, jak se konečný produkt-představení vyvíjelo. Zmíněná pravdivost se tedy váže $\mathrm{k}$ časové ukotvenosti scénografie, činící $\mathrm{z}$ ní umění $\mathrm{v}$ procesu. $\mathrm{V}$ tomto kontextu může při pozorování takových artefaktů dojít k napojení na onu nezachytitelnou akci, pro niž původně vznikly a která tak i přes svou absenci zůstává v rámci vystavení př́tomná. Obdobnou kvalitu přisuzuje Aronson i artefaktům konkrétních inscenací (např. kostým), které však vystavením ztrácí svůj kontext a stávají se samostatným uměleckým dílem. Jinými slovy se tedy při statickém vystavení scénografických artefaktů ztrácí jejich původní specifika a vytváří se nová - výstavní, přičemž jsou následně posuzovány odlišnou estetickou optikou. Tato skutečnost může být (vedle technologického pokroku a ekonomicko-praktických důvodů) také jednou z př́čin, proč se současné $P Q$ vzdaluje od způsobu vystavování prostřednictvím artefaktů.

Shrnout můžeme, že výstavní scénografie byla $\mathrm{v}$ teoretických textech i v praktické rovině široce rozebírána již $\mathrm{v}$ dobách vzniku $P Q$ a to jak $\mathrm{v}$ otázkách prostoru, času a kontaktu s publikem, tak i ve vztahu k specifické živosti její výstavní řeči, pomocí které se měla organizovat interakce exponátu s divákem. Evidentní jsou také paralely mezi profesemi jako „autor výstavních scénářü “, existujícími v rámci výstavní tvorby v období 60. let, a současnými národními kurátory. Ti dnes stejně jako kdysi autoři výstavních scénářů připravují své národní expozice a vybírají prezentované artefakty či umělce, kteří instalaci navrhnou. Naopak jako fenomén původní podobě $P Q$ cizí by se aktuálně mohla jevit jistá „živost“, tedy současné tendence oživovat výstavní expozice a pojímat je performativním způsobem. Tyto tendence se sice mohou jevit $\mathrm{v}$ opozici vưči spíše statickým způsobům vystavování, charakteristickým pro dobu vzniku akce, nicméně otázka „živé prezentace“ doprovází $P Q$ od dob jeho vzniku. Jak vysvětluje výše citovaná Barbora Příhodová, už po prvním úspěšném ročníku $P Q$ - v uvolňující se atmosféře roku 1968 - se navrhovalo, aby výstavu doprovázel i mezinárodní divadelní festival

18 Nutno podotknout, že Aronson tímto přirovnáním odkazuje k místu konání $P Q$ 2007, kdy přehlídka nebyla rozptýlena do různých budov jako např́ḱlad v roce 2015, ale naopak se uskutečnila v jediném prostoru holešovického výstaviště (kam se opět vrátila v roce 2019). 
(PŘíHODOVÁ 2012b). Evidentně tedy už tehdy panovalo přesvědčení, že by výstavní expozice měly být doplněny živou akcí. Vzhledem k následnému politickému vývoji však nebyl tento nápad realizován, nebot, jak upozorňuje Př́íhodová, bylo vystavování fixních jevištních a kostýmních návrhů snadněji kontrolovatelné než „nepředvídatelné“ živé akce. ${ }^{19}$ Vracíme se tím opět ke specifiku doby, tj. k politicko-společenské situaci, ve které $P Q$ vzniklo jako soutěžní přehlídka. V tomto směru mohly výstavní formy typu „scénografický artefakt“ navíc posloužit i jako vhodný vývozní artikl, kdy kontrolu kontextu prezentace zajištoval např́íklad výstavní scénář.

Přestože tedy Pražské Quadriennale nemělo na dlouhou dobu jinou možnost než převážně vystavovat velkolepé reprezentativní scény, je nicméně pravděpodobné, že i alternativní umělecké formy vystavení si postupně nacházely svou cestu. Takovou hypotézu můžeme vyvodit například z hodnotícího textu Vladimíra Jindry k druhému ročníku PQ 1971, na který upozorňuje Barbora Příhodová (2012b). Jindra zde uvádí následující: „PQ ukázalo, že scénografie vyžaduje zvláštní specifikum instalace. Neměl by to být způsob galerijního vystavování, poněvadž podstatě scénografie neodpovídá. Mělo by se pro její vystavování vytvořit ,divadelní prostředí. Ostatně o tento způsob instalace se už na tomto PQ několik expozic pokoušelo. A lze očekávat, že se bude vývoj výstavy v tomto smyslu ubírat i v budoucnu" (GABRIELOVÁ 2007: 57).

Pakliže se tak dnešní směřování $P Q$ vzdaluje od své původní koncepce, jedná se především o posun v celkovém záměru akce: od přehlídky toho nejlepšího, co vzniklo v jednotlivých zemích (za poslední čtyři roky) na poli divadla a scénografie, s expozicemi koncipovanými především jako zdroj informací o tom, jak je scénografie $\mathrm{v}$ jednotlivých zemích vytvářena (jaké jsou tamní umělecké rukopisy scénografů a režisérů a způsoby ztvárňování divadelních inscenací), se dostáváme k tvořivé události bez fixního ohraničení termínu „scénografie“. Cílem je nyní prozkoumávat, promýšlet a odhalovat, co vše scénografie je a kde všude ji můžeme nalézt, co do ní zahrnout a jak s ní pracovat. Svými výstavními formami tedy $P Q$ po návštěvnících vyžaduje, aby se sami prostřednictvím interakce zamysleli nad tím, jak je vůbec možné scénografii vystavit v kontextu její „živosti“. Pokračuje se tak v jistém smyslu v cestě, kterou v roce 1971 naznačil Vladimír Jindra - vytváří se specifické instalace, charakteristické svým „divadelním“ uspořádáním. Následujícími analýzami vybraných (osobně prožitých) expozic se pokusím toto tvrzení doložit.

19 Autorka studie vysvětluje, že se myšlenky zpochybňující vystavení scénografie prostřednictvím kreseb či malovaných návrhů začaly objevovat prakticky hned se vznikem $P Q$. Jako příklad uvádí hodnotící kritéria, v nichž nebyla posuzována pouze vizuální hodnota výtvarného návrhu, ale i funkce dané scénografie v kontextu celého představení a ve vztahu ke způsobu inscenování hry. Příhodová také upozorňuje na skutečnost, že opět prakticky od vzniku $P Q$ můžeme vypozorovat i tendenci pojímat scénografii coby efemerní umění - jistý „proces v prostoru“. Jinými slovy zde vidíme chápání scénografie nikoliv pouze jako konkrétního hmotné řešení, ale spíše coby finálního „jevištního“ výsledku: „[...] a tendency toward the performative that transcends the art of theatre and the visual arts" (PŘíHODOVÁ 2012b: 8). 


\section{Expozice Nekonečná duna}

V souvislosti s organizováním výstavních expozic se často setkáváme s pojmem instalace, jenž na obecné úrovni označuje nejrůznější rozmistování předmětů pro výstavní účely. Zároveň ale instalaci můžeme charakterizovat i jako svébytné umělecké médium, jehož základní teoretické pojednání představuje například esej Michaela Frieda Art and Objecthood. Zde je mj. zdůrazněn teatrální charakter umění instalace, umožňující pozorovateli ponořit se do díla a senzoricky jej vnímat. Friedova studie také stanovuje základní faktory, které instalaci charakterizují: její dočasná povaha, závislost na konkrétní situaci, úzké zaměření na diváka (FRIED 1998). Dánská teoretička uměni Anne Ring Petersen dodává, že instalace představuje přechod mezi klasickými žánry umění, nebot' využívá všechny druhy médií a spojuje je nejrůznějšími způsoby. Uměleckou instalaci proto považuje za specifické pole obsahující nejrůznější formy vyjádření, o čemž svědčí termíny jako video installation, sculpture installation, performance installation, site specific installation a mixed media installation (PETERSEN 2009: 46).

Se specifickými instalacemi se mohl návštěvník setkat snad během každého ročníků $P Q$ a jinak tomu nebylo ani v červnu 2019, kdy se uskutečnil doposud poslední, čtrnáctý ročník. V jedné z rozsáhlých hal Průmyslového paláce se nacházela i mad’arská národní expozice nazvaná Nekonečná duna/Infinite Dune. Tvořila ji prostorově výrazná instalace, na čtyřech sloupech vyvýšená rozměrná krychle pokrytá reflexními plochami. Pokud se návštěvník postavil na připravené stoličky pod krychlí, mohl se dostat přímo dovnitř instalace. V takovém případě jeho hlava zmizela v zářící kostce, zatímco zbylá část těla zůstala viditelná ostatním návštěvníkům výstavního pavilonu (obr. 7, 8 a 9). Uvnitř instalace, tedy v izolované zóně, čekala na návštěvníka ona nekonečná duna. Tvořily ji opět zrcadlové plochy pokrývající vnitřní stěny krychle a imitace písku, rozmístěná v různých nánosech po její spodní části. Vykukující a opět se ztrácející hlavy návštěvníků se zde díky hře zrcadel porůznu množily a deformovaly, což doprovázela uklidňující ambientní hudba a tlumená měnící se světelná kompozice. Nutno přitom zdůraznit, že se Nekonečná duna nacházela na rozsáhlé a rušné výstavní ploše, a tedy v těsné blízkosti mnoha okolních expozic. O to výrazněji vynikal jistý paradox izolace, kterou návštěvník mohl v rámci instalace zakusit: zatímco tělo zůstalo součástí pulzujícího světa výstavy, hlava se ocitla v jiné realitě. Byt by se mohlo zdát, že šlo o metaforické „strkání hlavy do písku“, jednalo se spíše o navazování „nových spojení“. Uvnitř duny totiž většinou nikdo nebyl sám, at už se jednalo o variace vlastní tváře na zrcadlových plochách či o jiné návštěvníky (v jedné chvíli se mohlo do instalace zapojit alespoň šest návštěvníků - tj. ve spodní části bylo minimálně šest otvorů).

Z popisu vyplývá, že zásadní zde byla osobní zkušenost - prožitek instalace - propojená s okolním prostředím výstavního pavilonu. Jak navrhuje výše citovaná Anne Ring Petersen, je cílem umění instalace transponovat realitu na jinou úroveň. K tomu dochází zejména pomocí různých divadelních technik, jako je spolupůsobení publika jakožto spolu-aktéra, díky kterému instalace nabírá až rituální rozměry. Umění instalace tak můžeme chápat jako inscenování obrazů a fikce svého druhu, které vzniká jako pomyslné jeviště „[...] for the observer to enter - a spatial structure spread out about the observer 

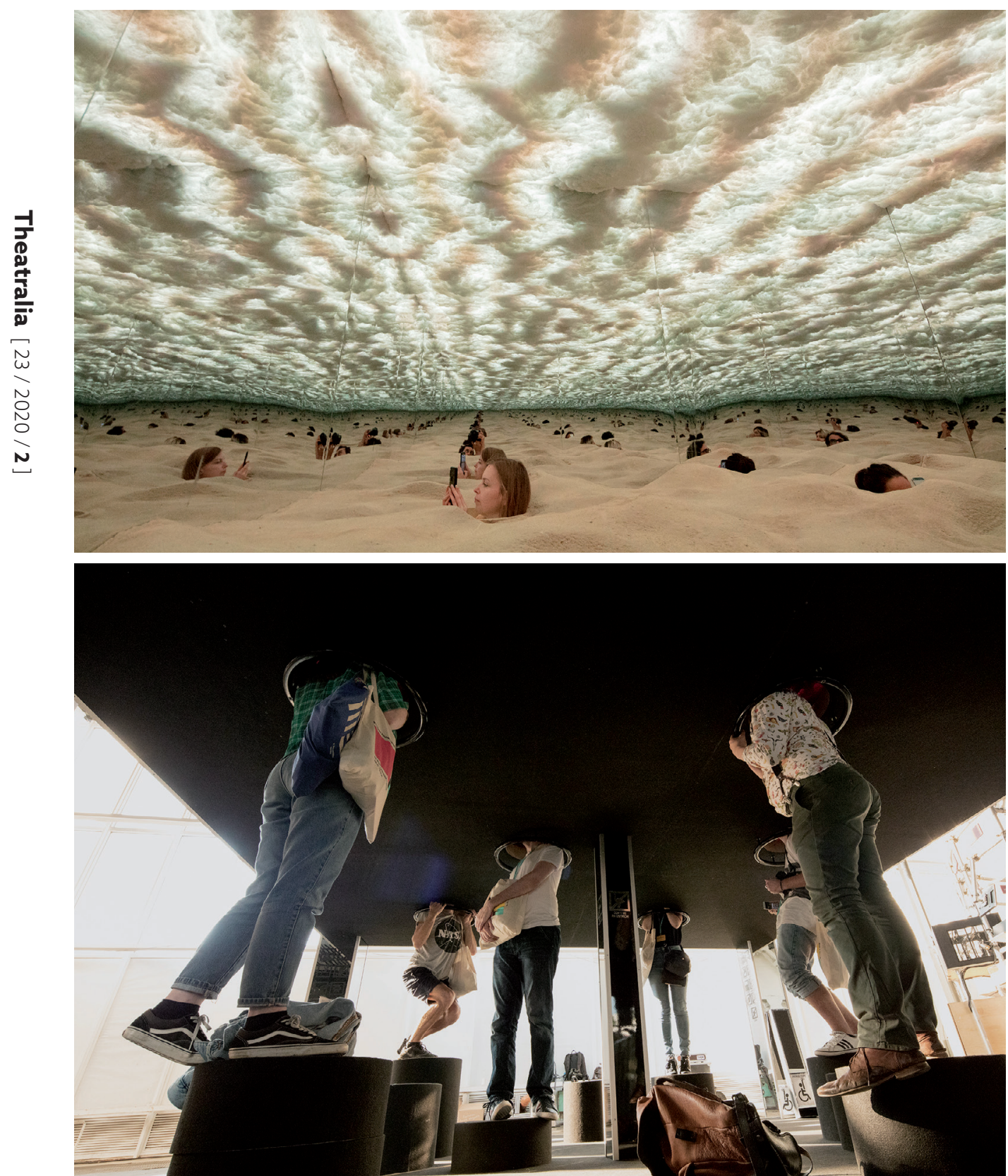

Obr. 7 + 8: Expozice Nekonečná duna/Infinite Dune. Mad'arsko. PQ 2019. Foto András Juhász. Dostupné online na https://www.pq.cz/projects/event-detail-en/?exhibition=29. 


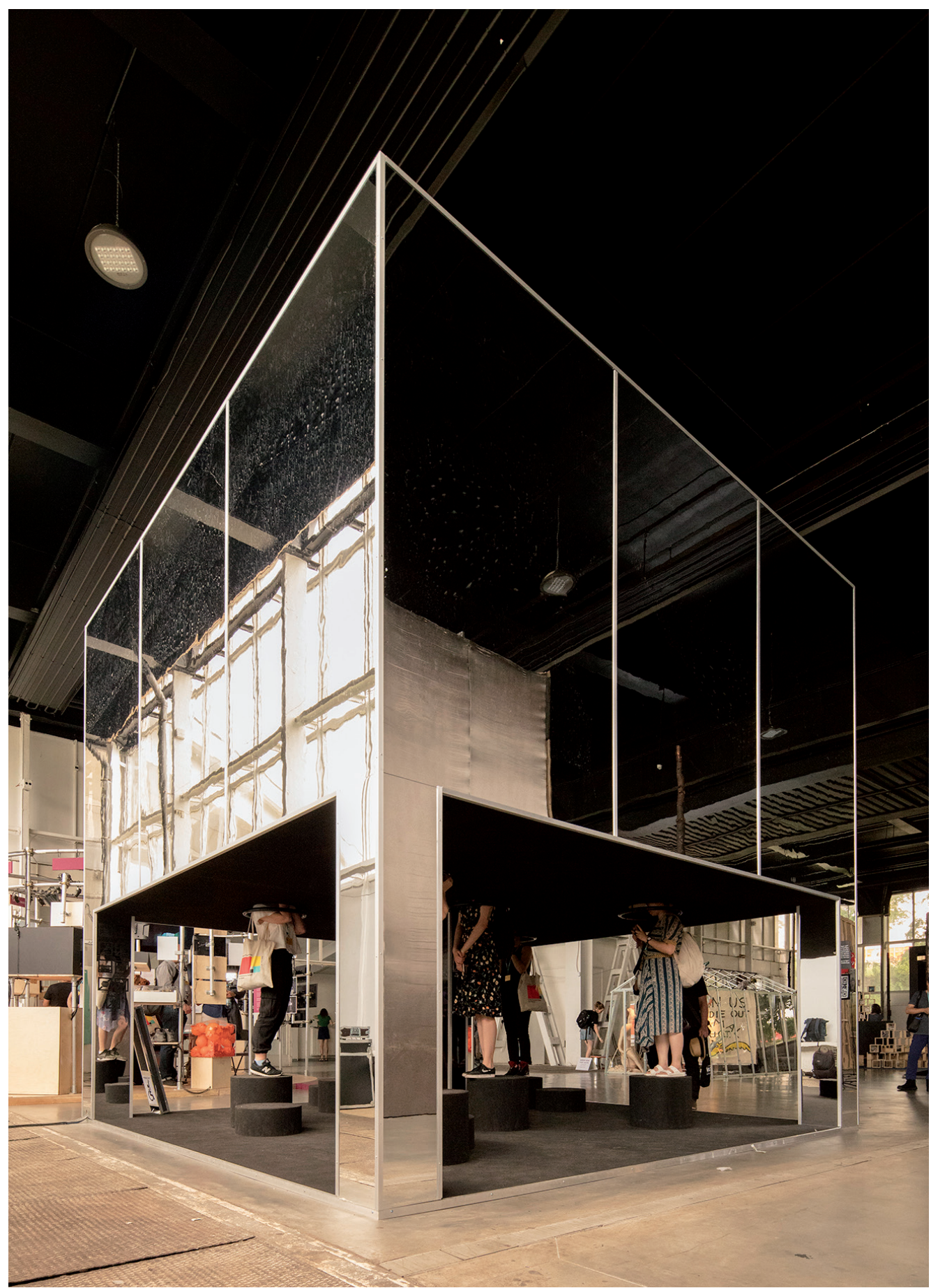

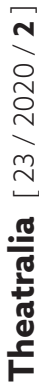

Obr. 9: Expozice Nekonečná duna/Infinite Dune. Mad'arsko. PQ 2019. Foto András Juhász. Dostupné online na https://www.pq.cz/projects/event-detail-en/?exhibition=29. 
who is to be involved in the art experience as a situation or an event" (PETERSEN 2009: 49). Svou teatrální a performativní povahou odvrací médium instalace pozornost od samotného díla směrem ke zkušenosti, kterou jeho prostřednictvím může pozorovatel získat. Jak dokazuje př́ílad mad’arské expozice, setkáváme se v rámci umění instalace s dílem v procesu, pro něž je zásadní živá akce. Instalace Nekonečná duna zároveň demonstruje jeden ze způsobů, jakými jsou současné výstavní expozice konstruovány směrem k divákovi - návštěvníkovi $P Q$, který je nejen zažívá a nechává existovat ve své mysli, ale nezř́ídka je i sám spolu-vytváří v prostoru reálném (okolní výstavní ploše). Výstavní projekty tedy „ožívaji“ s těly performerů; teprve živá akce aktivizuje výstavní prostor a prítomným objektům propůjčuje zcela jiný kontext tím, že s nimi vstupuje do interakce. Francouzský filozof Maurice Merleau-Ponty v kontextu analýzy vnímání upozorňuje, že fenomenologický svět není čisté bytí, ale smysl, který prosvítá tam, kde se protínají naše zkušenosti se zkušenostmi druhého, ,[...] tam, kde do sebe tyto zkušenosti navzájem zapadaji“" (MERLEAU-PONTY 2013: 25). Fenomenologický svět je tak stejně jako každý (umělecký) prožitek návštěvníka $P Q$ neoddělitelný od subjektivity a intersubjektivity. Jednota se přitom utváří až přejímáním minulé zkušenosti do zkušeností přítomných, přejímáním zkušeností druhého do své vlastní. ${ }^{20}$

\section{Expozice MUÉRETE}

Výše uvedené postř̌ehy můžeme aplikovat také na španělskou národní expozici s názvem MUÉRETE z PQ 2015. Její autoři v doprovodném textu uvedli, že expozice „pracuje s metaforickou smrtí jako prostředkem k očištění a vzkř̌řsení“ (Archiv PQ 2015: Španělsko). Aby se tak stalo, přetvořil autor koncepce José Luis Raymond jednu z místností barokního Colloredo-Mansfeldského paláce v pohřební komoru: stěny, podlahu i strop se starobylými tapetami nechal pokrýt hutným materiálem zlatavé barvy, přičemž i vchod a východ z místnosti zakryl zlatými závěsy. Do středu přiděleného prostoru dále umístil rozměrný katafalk a po obvodu komory nechal rozestavět dřevěné lavičky. Ústřední bod expozice tedy tvořil právě katafalk, který se skládal ze dvou stupňů: spodního z plexiskla, uvnitř kterého spočívalo mnoho předmětů každodenní potřeby, a vrchního ze dřeva (obr. 10).

Na příchozího návštěvníka zde čekaly dvě možné podoby výstavní místnosti: bud’ se na horní části katafalku nenacházelo nic hmotného a divák tak mohl pozorovat pouze projekci hemžících se červů (promítanou ze stropu). V druhém případě na vyvýšeném pietním místě pro vystavení rakve ležel člověk - nikoliv k tomuto účelu oslovený performer, ale náhodný návštěvník expozice. Výstavní koncept totiž k takovému aktu přímo vybízel, a to jak explicitně v doprovodném textu, tak implicitně svým prostorovým

20 Expozice $P Q$ tak může zacházet $\mathrm{s}$ tělem performera jako $\mathrm{s}$ objektivním prostorem, kdy se jeho prostřednictvím pojímá vněǰši předmět - právě tělo totiž objasňuje a umožňuje smyslový prožitek. Teorie vnímání prostřednictvím pocitování vlastního těla, a to pod objektivním věděním (které naopak poznává tělo z odstupu), nás přivádí k otázce prožitku výstavní expozice, která má za cíl simulovat prožitou zkušenost či zcela neznámou naraci. 

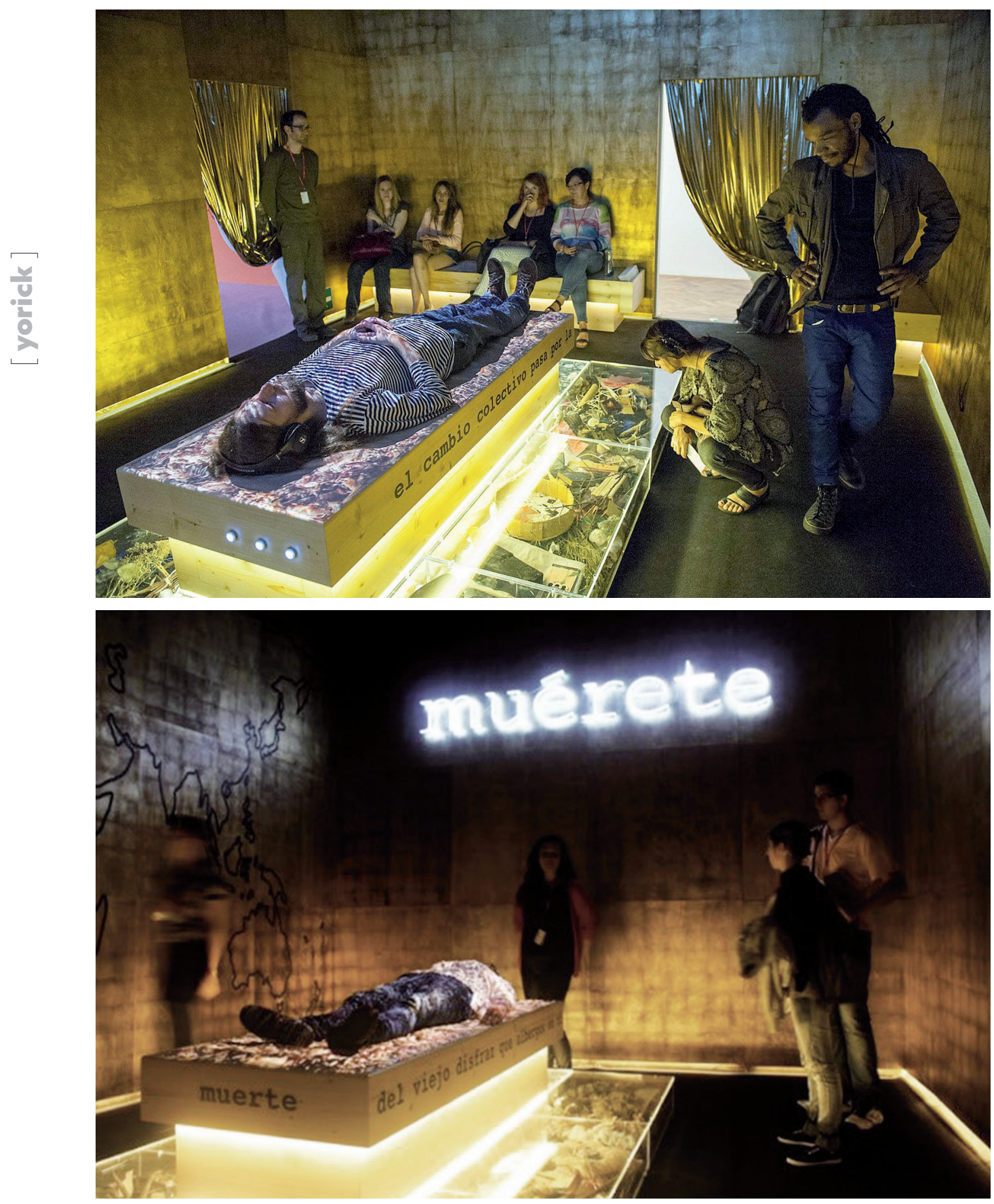

Obr. 10 + 11: Expozice MUÉRETE. Španělsko. PQ 2015.

Foto David Pastor. Dostupné online http://2015.pq.cz.s3.amazonaws.com/ www/program/spanelsko.htm/\#\&gid=undefined\&pid=17. 
uspořádáním (například na katafalku připravenými sluchátky). Pakliže návštěvník výzvu přijal a na připravené místo si lehl, stalo se jeho tělo - nyní odrážející projekci hemžících se červů - součástí expozice. Zároveň v tu chvíli ležící návštěvník zhmotňoval onu doposud chybějící mrtvolu, o čemž ostatní návštěvníky mj. spravoval velký nápis muérete („zemřít“), nacházející se nad hlavou ležícího člověka (obr. 11). Návštěva španělské „pohřební komory“ byla v obou vytyčených případech navíc silným smyslovým zážitkem - oproti jiným prostorám paláce zde totiž panovalo velké, až nepř́íjemné teplo, které mohlo v kombinaci s projekcí červů evokovat pocit všudypřítomného rozkladu. Vše navíc posilovala i materialita komory: například stěny obložené hutným a neprodyšným materiálem připomínajícím kůži, jenž se při dotyku lepil a specificky zapáchal.

U popisované expozice se kromě toho setkáváme ještě s další variantou „zažiti““ prostoru, než jsou dvě výše uvedené. Na toho, kdo přijal „nabídku“ a položil se na vyvýšené pietní místo, čekal prožitek založený na pocitu vlastního pohřbívání, tedy zcela jiný než u ostatních přihlížejících. Oné metaforické smrti, o které mluví autor koncepce, se u ležícího návštěvníka dosahovalo zvukově a vizuálně. Na stropě přímo nad katafalkem se nacházelo nahnuté zrcadlo, ve kterém mohl ležící pozorovat obraz vlastního těla obklopeného skrumáží předmětů, umístěných v dolní části podstavce z plexiskla. Popsaný výjev navíc pokrývala již zmiňovaná projekce pohybujících se červů, která živé tělo i okolní nehmotné předměty pomyslně zahalovala do právě probíhající fáze rozkladu. Připravená zde byla také sluchátka s reprodukovanou ambientní hudbou, po jejichž nasazení se mohl účastník sluchově izolovat od zbytku místnosti a libovolný čas se soustředit jen na pozorování - prožívání vlastní metaforické smrti.

Jak je uvedeno výše, fenomenologický svět je smysl, který prosvítá tam, kde se protínají zkušenosti naše se zkušenostmi druhého - podobně mohl v rámci výstavy MUÉRETE návštěvník objevit její smysl až formou prožitku, at již vlastního (ulehnutím na katafalk) nebo jiného návštěvníka (jeho interakcí s připraveným prostorem). Jednota smyslu expozice se přitom utvářela až přejímáním minulé zkušenosti do zkušeností př́itomných, přejímáním zkušeností druhého do své vlastní. Nebot i ten, kdo prožil vlastní metaforickou smrt, nejprve vešel do místnosti a okusil ji jiným - řekněme „primárním“ způsobem. Pro fenomenologii vnímání je zásadní tělo a tělesná intencionalita, což jsou pojmy taktéž klíčové pro španělský výstavní projekt, ve kterém se stav mysli pomocí odrazu živého těla (a dalších podpůrných prvků jako zápach a zvuk) dostal za pomyslný prostorový horizont. $\mathrm{K}$ prostoru a časovosti se zde tedy přistupovalo prostřednictvím těla: rozhodl-li se návštěvník položit se doprostřed místnosti a vytvořit tím ze svého těla výstavní objekt, definoval jím strávený čas na katafalku jednak prostorový, jednak i časový horizont prožitku expozice návštěvníků ostatních, tj. přihlížejících.

Za zásadní prvek španělské výstavy tak můžeme označit tělo, které je v rámci fenomenologie vnímání chápáno jako vlastní náhled na svět, který „neustále udržuje naživu podívanou, na niž lze patřit [...]“ (MERLEAU-PONTY 2013: 255). Rozhodnul-li se návštěvník vstoupit do vnitřního prostoru expozice, a stát se tak zdrojem podívané pro ostatní - udržovat naživu podívanou, na niž lze patřit, - získal tím zkušenost vedoucí k vlastnímu pohledu na prezentovaný výjev, pohledu odlišnému od pohledu ostatních přihlížejících, které tímto činem modifikoval na publikum a sebe na aktéra. Záměrně 
přitom volím termín „publikum“, a ne „spolu-aktér“, nebot prožitek z nabízeného položení se na katafalk mohl být uskutečněn i bez př́itomnosti ostatních lidí, přestože s nimi vytvářel jiné (snad radikálnější) konotace.

\section{Závěr}

Výše představené výstavní expozice $P Q 2015$ a $P Q 2019$ prokazují, že různé realizace této akce můžeme nahlížet i optikou tzv. „divadla jako zážitku“. Jedná se o snahu pojmout svět nikoliv z abstraktní vědecké perspektivy, ale naopak z perspektivy subjektu - první osoby. Základní otázkou je potom to, jak se svět jeví jako fenomén lidem, kteří se s ním setkávají. $V$ rámci teatrologie znamená tento přístup pokus o zachycení divákovy zkušenosti $\mathrm{v}$ její prvotní podstatě, ,[...] než začne být zpracovávána na intelektuální úrovni. Při analýze představení (či performance) totiž provádíme umělou rekonstrukci [...] představení či události, vybíráme, uspořádáváme a do jisté míry předěláváme tuto ,zkušenost" a její prvky." (BERNÁTEK, DROZD a HAVLÍČKOVÁ KYSOVÁ 2014: 50-51)

Uvedené můžeme dále abstrahovat a slovo „svět“ nahradit pojmem „scénografie“ a ptát se, jak se scénografie jeví jako fenomén lidem, kteří se s ní setkávají během $P Q$ jak na nás scénografie působí smyslově, zda se nám prvoplánově líbí, co při pohledu na ni pocitujeme, jaké stavy nám navozuje a podobně. Fenomenologie se staví do opozice vůči sémiotice a důraz klade na smyslový dojem divadla, což se projevuje především v zaměření na diváka. Scénografické expozice se tedy zjednodušeně řečeno ukazují smyslům diváka a záměrně se staví do role něčeho, co má být viděno, slyšeno či případně procítěno jinak (např. ochutnáno - jako v případě tvorby jahodových knedlíků během projektu Praha neni Česko). Takto pojaté projekty mají v posledních ročnících $P Q$ nejen své místo, ale jsou navíc často vyzdvihovány mezinárodní porotou prostřednictvím jejich ocenění v jednotlivých soutěžních kategoriích. Dostáváme se tím opět k fenoménu samotné scénografie a všeho, co zahrnuje. A jak uvádí i Arnold Aronson: "If the PQ is seen as a barometer of world scenography, then the purely visual, concrete, and semiotic aspects of scenography are being replaced by the spatial, the temporal, and the intangible" (ARONSON 2018: 12).

Přihlédneme-li k uvedenému kontextu vzniku $P Q$ a k tomu, co v té době scénografie představovala, můžeme si spolu s dalšími teoretiky i praktiky položit otázku, zda je tématem současných ročníků $P Q$ ještě vůbec samotná scénografie. Chápeme-li scénografii v uvedených dobových souvislostech (tj. coby exkluzivní formu jevištního výtvarnictví a jako integrovanou součást divadelní inscenace), bude znít odpověd’ negativně. $\mathrm{Na}$ představených způsobech vystavování scénografie je totiž patrné, že se pojímání tohoto uměleckého žánru odchýlilo od jeho pevného spojení s divadelním artefaktem. Přestože jsou totiž mnohé výstavní expozice nadále tvořené prostřednictvím dokumentárních forem, tedy jako jisté oživování uplynulých divadelních produkcí, nezřídka je nyní cílem vytvořit „teatralizované prostředi“ - tj. instalaci založenou na performativním jednání aktérů i návštěvníku-spoluaktérů a nabízející návštěvníkům hned několik druhů zážit- 
ků. Není proto zřejmě překvapivá ani jistá oscilace mezi kategoriemi jako výstava versus festival či scénografie versus performance design, která $P Q$ jakožto událost „udržuje“ v napětí mezi výtvarným a divadelním uměním. $Z$ uvedeného také vyplývá, že způsoby vystavování scénografie účastnících se zemí budou patrně vždy odrážet trendy a posuny v tvorbě i vnímání tohoto pojmu, ke kterým dochází takřka neustále.

Vrátíme-li se k úvodu studie a navrženému konstatování, že scénografie je dnes na $P Q$ prezentována jako svébytná transdisciplinární praxe výtvarného ztvárňování performativních prostorů, můžeme takto definovanou scénografii chápat i jako každodenní realitu. $\mathrm{V}$ té je působení každého z nás performativním aktem, vážícím se $\mathrm{k}$ méně i více pevně nastaveným (společenským) rolím, prostorům a celkovým vzorcům našeho působení ve společnosti v tom nejširším smyslu. A je-li scénografie prostorově-výtvarné ztvárnění tohoto našeho jednání, podává svou podobou věrnou zprávu o stavu našeho světa. Ve scénografickém pojetí posledních $P Q$ je tento svět roztřišstěný, chaotický, těkavý, interaktivní a přeplněný vizuálními obrazy našeho mediálního života. Stejně tak jako zde chybí jasné ohraničení toho, co je jeviště a co hlediště, chybí i ohraničení procesu vnímání a „překládání“ viděné skutečnosti, ke kterému tak dochází takřka konstantně. Zrušíli se takto nastavené hranice, budou se jistě stále častěji ozývat hlasy tázající se po smyslu akce, která chce prezentovat scénografii, a přitom jí takřka nedisponuje. Ovšem ono „odhmotnění“ scénografie je zároveň odpovědí, nebot̉ jde o upozorňování na scénografické prostředky každodenního života, jež nás obklopují, aniž by nutně musely mít hmotnou, např́klad architektonickou formu.

\section{Bibliografie}

Archiv Pražského Quadriennale scénografie a divadelního prostoru 2015 [online]. Estonsko - Sjednocené Estonsko. Archiv PQ [online]. Praha [cit. 10. 6. 2020]. Dostupné online na http://2015. pq.cz.s3.amazonaws.com/www/program/estonsko.html.

Archiv Pražského Quadriennale scénografie a divadelního prostoru 2015 [online]. Francie. Archiv PQ [online]. Praha [cit. 10. června 2020]. Dostupné online na http://services.pq.cz/cs/pq-67. html?itemID=61\&type=national.

Archiv Pražského Quadriennale scénografie a divadelního prostoru 2015 [online]. Mezinárodni výstava zemi. Ceny PQ. Archiv PQ [online]. Praha [cit. 10. 6. 2020]. Dostupné online na http://2015.pq.cz.s3.amazonaws.com/www/program/mezinarodni-vystava-zemi/ceny-pq. html.

Archiv Pražského Quadriennale scénografie a divadelního prostoru 2015 [online]. Španělsko Muérete. Archiv PQ [online]. Praha [cit. 10. 6. 2020]. Dostupné online na http://services. pq.cz $/ \mathrm{cs} /$ pq-15?itemID $=497 \&$ type $=$ national.

Archiv Pražského Quadriennale scénografie a divadelního prostoru 2019 [online]. Mad'arsko Nekonečná duna. Archiv PQ [online]. Praha [cit. 10. 6. 2020]. Dostupné online na https://www. pq.cz/cs/projekty/event-detail-cz/?exhibition=29.

ALBERTOVÁ, Helena. 2009. Rozhovor. In Alena Součková, Jarmila Svobodová a Helena Albertová (edd.). Divadelní ústav 1959-2009. Praha: Institut umění - Divadelní ústav, 2009. 
ARONSON, Arnold (ed.). 2018. The Routledge Companion to Scenography. London: Routledge, 2018. ARONSON, Arnold. 2008. Exhibiting Scenography: the Loss of the Artifact. In Arnold Aronson (ed.). Exhibition of the Stage: reflections on the 2007 Prague Quadrennial. Praha: Institut umění Divadelní ústav, 2008.

ARX, Serge von, Simon BANHAM a Sodja LOTKER et al. (edd.). 2015. PQ 2015: Pražské Quadriennale scénografie a divadelního prostoru. Praha: Institut umění - Divadelní ústav, 2015.

BISHOP, Claire. 2007. Řízení reality. Spolupráce a participace v současném umění. Sešit pro umění, teorii a př́buzné zóny 1 (2007): 1-2: 9-36.

BERNÁTEK, Martin, David DROZD a Šárka HAVLÍČKOVÁ KYSOVÁ. 2014. Úvod do teorie divadla: vybrané kapitoly. Brno: Masarykova univerzita, 2014.

BREJZEK Thea, Lawrence WALLEN a Stephan A. DI BENEDETTO. 2018. The Model as Performance: Staging Space in Theatre and Architecture. London: Methuen Drama, 2018.

FANTOVÁ, Markéta a Brad Caleb LEE et al. (edd.). 2019. Prague Quadrennial of Performance Design and Space. Catalogue. Praha: Institut umění - Divadelní ústav, 2019.

FISCHER-LICHTE, Erika. 2001. Ästhetik des Performativen. Frankfurt am Main: Suhrkamp Verlag KG, 2004.

FRIED, Michael. 1998. Art and Objecthood: Essays and Review. Chicago: University of Chicago Press, 1998.

GABRIELOVÁ, Jarmila. 2007. Kronika Pražského quadriennale. Praha: Institut umění - Divadelní ústav, 2007.

HANN, Rachel. 2018. Beyond Scenography. London: Routledge, 2018.

HERMAN, Josef (ed.). 2015. PQ na rozcestí, nebo na konci cesty? [online]. Divadelni noviny 1. 9. 2015 [cit. 10. 6. 2020]. Dostupné online na https://www.divadelni-noviny.cz/pq-narozcesti-nebo-na-konci-cesty.

JINDRA, Vladimír a Věra PTÁČKOVÁ (edd.). 1967. PQ 67: Prǎ̌ské Quadriennale jevištního výtvarnictvi a divadelni architektury. Praha: Divadelní ústav, [1967].

JINDRA, Vladimír, Edita MALIAROVÁ a R. A. BABEL (edd.). 1971. PQ 71: Pražské Quadriennale jevištniho výtvarnictvi a divadelni architektury: Bruselský pavilón a Sjezdový palác v Parku kultury a oddechu Julia Fučika v Praze. Praha: Divadelní ústav, 1971.

LOTKER, Sodja. 2015. Jaké problémy a tendence odkryje letošní Quadriennale scénografie a divadelního prostoru? [online]. Materialtimes.com (29. 4. 2015) [cit. 10. 6. 2020]. Dostupné online na https://www.materialtimes.com/ptame-se/jake-problemy-a-tendence-odkryje-letosni-quadriennale-scenografie-a-divadelniho-prostoru.html.

MAGID, Václav. 2008. Konstruovaná situace a její okamžik v čase. Sešit pro teorii, uměni a př́buzné zóny 2 (2008): 4-5: 33-60.

MERLEAU-PONTY, Maurice. 2013. Fenomenologie vnímáni. Praha: Oikoymenh, 2013.

MCKINNEY, Joslin a Philip BUTTERWORTH. 2009. The Cambridge Introduction to Scenography. Cambridge: Cambridge University Press, 2009.

MCKINNEY, Joslin, Sodja LOTKER a Barbora PŘÍHODOVÁ. 2016. The Prague Quadrennial of Performance Design and Space 2015. Theatre and Performance Design 2 (2016): 1-2: 5-16.

MCKINNEY, Joslin a Scott PALMER (edd.). 2017. Scenography Expanded: An Introduction to Contemporary Performance Design. London: Methuen Drama, 2017.

NEKVINDOVÁ, Terezie, Daniela KRAMEROVÁ, Henrieta MORAVČÍKOVÁ, Martin STRAKOŠ, Martin BERNÁTEK, Vladimíra BÜNGEROVÁ a Marta SYLVESTROVÁ. 2017. Automat na výstavu: československý pavilon na Expo 67 v Montrealu. Cheb/Praha: Galerie výtvarného umění v Chebu/Akademie výtvarných umění, 2017. 
PATOČKOVÁ, Jana. 2009. Z historie divadelního ústavu. In Alena Součková, Jarmila Svobodová a Helena Albertová (edd.). Divadelni ústav 1959-2009. Praha: Institut umění - Divadelní ústav, 2009.

PETERSEN, Anne Ring. 2009. Realism, theatricality, ritual - On aspects of the aesthetics of the installation. In Sven Bjerkof (ed.). Reality Check. København: Statens Museum for Kunst, 2008: 44-61.

Praha neni Česko [online]. [cit. 10. 6. 2020]. Dostupné online na http://www.prahanenicesko.cz/. PROCHÁZKA, Antonín. 1966. Několik problémů kolem výstav. Acta Scaenographica 7 (1966): 1: $8,13-15$.

PŘíHODOVÁ, Barbora. 2012a. Obrazový prostor na jevišti k (re)konstrukci výtvarně-technického řě̌eni bostonské inscenace Intolleranza 1960 ve scénografii Josefa Svobody. Brno: 2012. Disertační práce. Masarykova univerzita. Filozofická fakulta, Katedra divadelních studií, nepubl.

PǨÍHODOVÁ, Barbora. 2012b. Towards the Performative: A Few Comments on Prague Quadrennial and its History [online]. [cit. 10. 7. 2016]. Dostupné online na http://services.pq.cz/cs/scenography-expanding.html?documentId=103\&type=detail\#top. Pův. Praški kvadrienale i njegova izvedba. Kazalište 51/52 (2012): 170-183.

PTÁČKOVÁ, Věra. 2009. Rozhovor. In Alena Součková, Jarmila Svobodová a Helena Albertová (edd.). Divadelni ústav 1959-2009. Praha: Institut umění - Divadelní ústav, 2009: 132-133.

SANTAR, Jindřich. Výstavy a výstavnictví. Acta Scaenographica 7 (1966): 1: 1-4.

SVOBODA, Josef. 1975. Scénografie ve výstavní tvorbě. In Zdeněk Lang a Václav Roštlapil (edd.). O výstavni tvorbě, sbornik sympozia. Brno: Svaz architektů ČSR/Brněnské veletrhy a výstavy, 1975: 23.

VOTRUBA, Bedřich. 1959. Nový obor výtvarného umění. Výtvarné uměni 9 (1959): 9: 415.

WALLING, Carl H. 2016. Exhibiting Scenographic Identities at the 2007 Ẽ 2011 Prague Quadrennials. Bowling Green: 2016. Dissertation thesis. Bowling Green State University, unpubl.

ZÁLEŠÁK, Jan. 2011. Uměni spolupráce. Praha: Akademie výtvarných umění v Praze, 2011. 


\section{Mgr. Bc. Amálie Bulandrová}

Katedra divadelních studií, Filozofická fakulta, Masarykova univerzita,

Arna Nováka 160200 Brno, Česká republika

bulandrovaamalie@gmail.com

Amálie Bulandrová absolvovala studium oborů Dějiny umění a Teorie a dějiny divadla na Filozofické fakultě Masarykovy univerzitě v Brně, kde nyní pokračuje v doktorském studiu. Ve své disertační práci se zabývá vizuální dramaturgií, tedy různými způsoby vizuálního ztvárňovaní performativních prostředí. Za účelem studia tohoto tématu absolvovala krátkodobý pobyt u prof. Knuta Ove Arntzena na University of Bergen. Během svých předešlých studií strávila rok v Německu (Ruhr-Universität Bochum, České Centrum Berlín) a rok ve Francii (Université de Poitiers; projekt Migrating Art Historians). Ve svém výzkumu se zabývá také fenoménem liturgického divadla, a to zejména $\vee$ kontextu dochovaných staveb coby potenciálních míst jeho produkce.

Amálie Bulandrová majored in Art History and Theatre Theory and History at the Faculty of Arts at Masaryk University in Brno, where she is continuing with her PhD studies. In her thesis she focuses on visual dramaturgy, i.e. various kinds of visual representation of the performance environment. As a part of her studies, she visited Professor Knut Ove Arntzen at the University of Bergen. She has also been on exchange programs in Germany (Ruhr-Universität Bochum, České Centrum Berlín), and France (Université de Poitiers; project Migrating Art Historians). Her research interest also lies within the field of the liturgical theatre, namely in the study of preserved medieval buildings as potential performance spaces. 